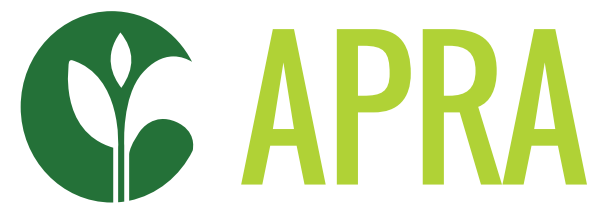

Agricultural Policy Research in Africa

\title{
THE POLITICAL ECONOMY OF THE MAIZE VALUE CHAIN IN NIGERIA
}

Paul Amaza, Sunday Mailumo and Asenath Silong 


\section{CONTENTS}

Acknowledgements and disclaimer

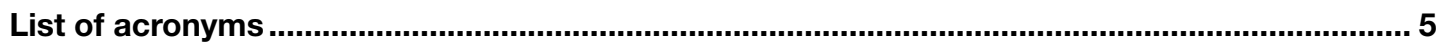

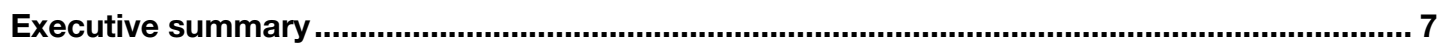

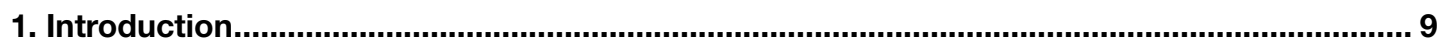

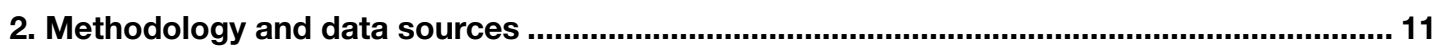

3. Context: the political economy of agricultural policy in Nigeria....................................... 12

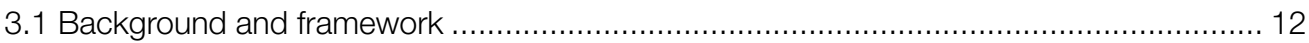

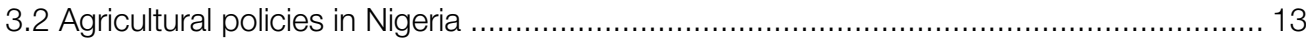

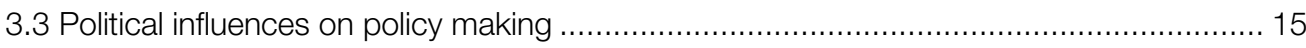

4. An overview of the MVC in Nigeria: examining its recent performance and key drivers ..... 17

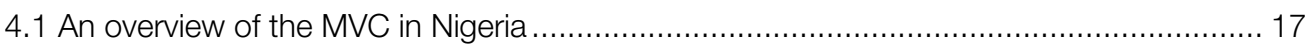

4.2 Performance of the MVC in Nigeria (2010-2019) …............................................ 18

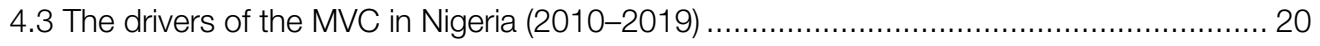

5. Detailed value chain mapping: Actors, processes and challenges ...................................... 24

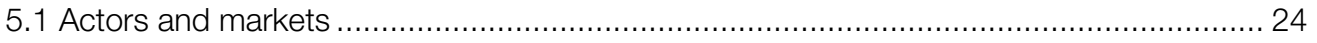

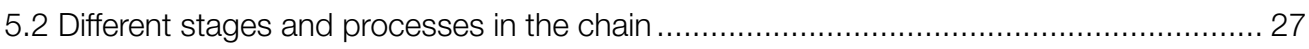

5.3 Challenges affecting the commercialisation and competitiveness of the MVC ................ 27

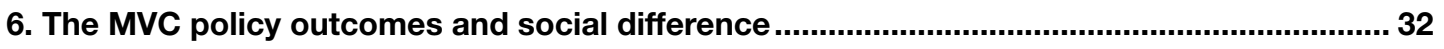

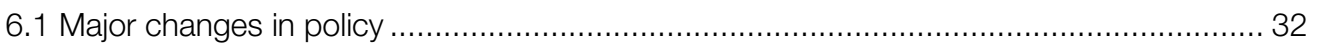

6.2 Current policies and regulations that govern participation in the MVC ........................ 34

6.3 The actors influencing policy decisions within the MVC ............................................... 35

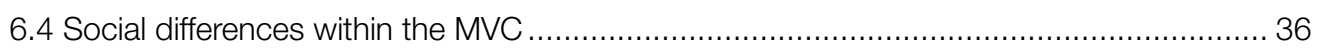

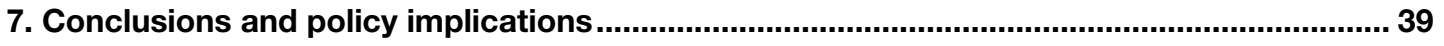

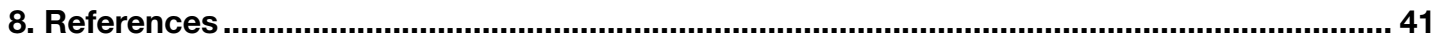

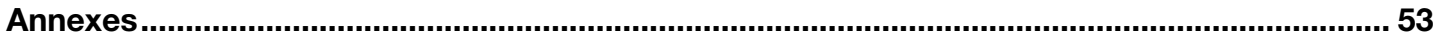

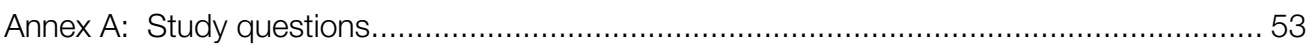

Annex B: A list of MVC actors that participated in the Klls ................................................ 53

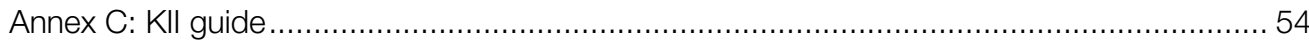

List of tables

Table 4.1: Production, area harvested, and yield of maize in Nigeria................................. 18

Table 4.2: Supply and demand for maize in Nigeria (million t) ........................................... 18 
Table 5.1: Changes in the amount of maize purchased before and after lockdown/COVID-19

among selected MVC actors in Nigeria

Table 5.2: Changes in the prices of maize grain as a result of lockdown/COVID-19 among

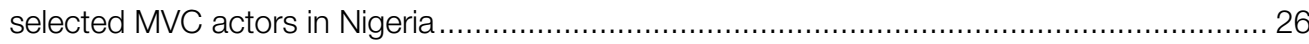

Table 6.1: Trends in certified maize seed production by type and year ................................. 33

\section{List of figures}

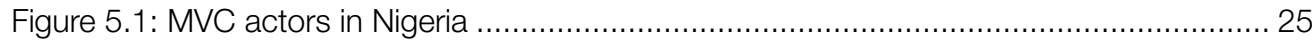

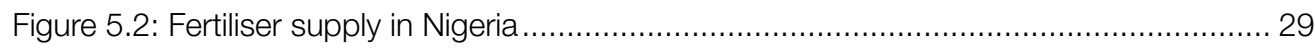




\section{ACKNOWLEDGEMENTS AND DISCLAIMER}

This research was conducted with funding from Agricultural Policy Research in Africa (APRA), a five-year research programme consortium funded by the Foreign, Commonwealth \& Development Office (FCDO). The programme, which is based at the Institute of Development Studies (IDS) (www.ids.ac.uk), builds on more than a decade of research and policy engagement work by the Future Agricultures Consortium (www.future-agricultures.org). We appreciate the cooperation of the actors along the maize value chain (MVC), in Kaduna and Plateau States, during the primary data collection. The actors are as follows:

1. Smallholder maize farmers' associations (rainy and dry season)

2. Commercial maize farmers

3. Fertilizer input suppliers

4. Seed companies (Da All Green Seeds and Premier Seeds)

5. Marketers (wholesalers)

6. Value addition/processors (Grand Cereals and NASCO)

7. Credit institutions (Bank of Agriculture)

8. Policy makers (Plateau ADP)

Many thanks to Zachariah Jamagani who assisted in data collection and interviews of stakeholders in the MVC. We also thank Prof. Blessing Chinsinga, Dr. Lars Otto Naess, and Stephanie Lynch for their insightful comments; and thanks to Olivia Frost for her work on the references.

Paul Amaza is a professor of Agricultural Economics and Director of the TetFUND Centre of Excellence in Food Security at the University of Jos, Nigeria. Sunday Mailumo joined the Forestry Research Institute of Nigeria in 2002 and was posted to the Federal College of Forestry, Jos, where he is teaching and carrying out research. Asenath Katugan Silong holds a PhD in Livelihoods (International Development and Applied Economics) from the University of Reading, UK.

This working paper is funded with UK aid from the UK government (Foreign, Commonwealth \& Development Office - FCDO, formerly DFID). The opinions are the authors and do not necessarily reflect the views or policies of IDS or the UK government. 


\section{LIST OF ACRONYMS}

\begin{tabular}{|c|c|}
\hline ADP & Agricultural Development Project \\
\hline AGRA & Alliance for a Green Revolution in Africa \\
\hline AMIS & Agricultural Marketing Information System \\
\hline APRA & Agricultural Policy Research in Africa \\
\hline APP & Agricultural Promotion Policy \\
\hline ATA & Agriculture Transformation Agenda \\
\hline CAADP & Comprehensive Africa Agriculture Development Programme \\
\hline CACS & Commercial Agriculture Credit Scheme \\
\hline CBN & Central Bank of Nigeria \\
\hline CIMMYT & International Maize and Wheat Improvement Center \\
\hline CMF & commercial maize farmer \\
\hline FAO & Food and Agriculture Organization of the United Nations \\
\hline FEPSAN & Fertilizer Producers and Sellers Association of Nigeria \\
\hline FMARD & Federal Ministry of Agriculture and Rural Development \\
\hline FMPA & Fadama Maize Producers Association \\
\hline FMSP & Federal Market Stabilization Program \\
\hline GDP & gross domestic product \\
\hline GES & Growth Enhancement Scheme \\
\hline IFC & International Finance Corporation \\
\hline IITA & International Institute of Tropical Agriculture \\
\hline IP & innovation platform \\
\hline KII & key informant interview \\
\hline MARKETS & Maximizing Agricultural Revenues and Key Enterprises in Targeted Sites \\
\hline MFA & Maize Farmers' Association \\
\hline MvC & maize value chain \\
\hline NABG & Nigeria Agribusiness Group \\
\hline NASC & National Agricultural Seed Council \\
\hline
\end{tabular}




$\begin{array}{ll}\text { NCS } & \text { Nigeria Customs Service } \\ \text { NEPAD } & \text { New Partnership for Africa's Development } \\ \text { NGO } & \text { non-governmental organisation } \\ \text { NIRSAL } & \text { Nigeria Incentive-based Risk Sharing for Agricultural Lending } \\ \text { NFDP } & \text { National Fadama Development Project } \\ \text { NPFS } & \text { National Policy on Food Security } \\ \text { OECD } & \text { Organisation for Economic Co-operation and Development } \\ \text { OPV } & \text { open pollinated varieties } \\ \text { SEDAN } & \text { Seed Producers and Distributors Association of Nigeria } \\ \text { SME } & \text { small and medium sized enterprise } \\ \text { SSA } & \text { Sub-Saharan Africa } \\ \text { USAID } & \text { United States Agency for International Development }\end{array}$


The aim of this case study is to understand the underlying political economy dynamics of the maize value chain (MVC) in Nigeria, with a focus on how this can contribute to comprehending the drivers and constraints of agricultural commercialisation. The study is informed by theories of political settlements, rents, and policy processes. It asks questions around (1) the key actors and interests: who participates and how do they benefit? (2) Rules and policies: who makes the rules, and who wins and loses? And (3), what are the implications across different social groups?

The focus on maize is motivated by the fact that it is one of the primary staple foods in the country. Nigeria is the tenth largest maize producer globally and the second largest producer in sub-Saharan Africa (SSA). Maize is the second most cultivated crop in Nigeria, in terms of area harvested (5.8 million ha), after cassava (7.1 million ha). It has high economic value due to its adaptability in the Guinea Savannah agro-ecological zone of the country. While an estimated 60 per cent of the maize produced in Nigeria is used for industrial purposes, its contribution to gross domestic product (GDP) is still low. This is partly because a considerable proportion is consumed locally with little value addition. The study was carried out during 2020 and early 2021. It is based on document analysis and key informant interviews (KIls) with commercial maize farmers and wholesalers.

Three key findings illustrate the political economy of the MVC in Nigeria. First and foremost, the high demand for maize products such as food, feed, and industrial raw material attracts many stakeholders' political interests. These include the political elites, policy makers, industrial processors, and traders. Notably, the political elite's interest in the MVC is mainly focused on the fertiliser inputs required in maize production, where they tend to benefit from the diversion of subsidised fertiliser from the government. Private sector processing industries and traders prefer to import maize because they profit from the relatively lower prices compared to domestically produced maize.

Second, changes in political regimes and associated policies present a challenge to dealers' and farmers' access to fertiliser and inputs. The government's constant effort to boost and improve smallholder farmers' productivity through policies intended to aid adoption and increase fertiliser use is yet to translate into an increase in sustainable agricultural production, rural household income, and livelihood. Most smallholder farmers fail to benefit from these government efforts and policies due to their poor implementation and targeting, as observed in the government's fertiliser policy. Despite the government's costly expenditure on fertiliser subsidies, most of the subsidised fertiliser falls into the hands of the private sector, who sell it at a higher price. At the same time, some subsidised fertiliser is exported through back doors to Nigeria's neighbouring countries, where it is sold at higher prices. Hence, it is reported that only a small quantity of subsidised fertiliser gets into the hands of small scale farm holders. This has caused smallholder farmers to conclude that the implementation of fertiliser subsidies in Nigeria is ineffective and inefficient.

The import regulation of maize is also a key factor in the political economy dynamics of the MVC. The national business strategy to source maize from domestic suppliers, means that the Nigerian government imposes strict foreign exchange measures, making it challenging to obtain import and export permits. However, due to growing demand in the feed sector, large feed mills and poultry farms occasionally obtain import permits to purchase foreign maize when they anticipate a significant shortfall in domestic supply. The underlining factors that drive the restriction of foreign imports of maize are essentially to i) ensure supply is bought from domestic sources, fetching higher prices for smallholder farmers and, ii) curtail the diversion of foreign exchange by importers for other profitable purposes instead of investing in the MVC. However, politically well-connected business people still undertake some regional trade. The informal cross border trade flows of maize between Nigeria and its neighbouring countries are concentrated on the KanoKatsina-Maradi region at the border with Niger. This corridor is characterised by flows of both local products and commodities from other countries.

Third, the social differentiation between men and women has direct implications for the prospects 
for commercialisation of the MVC in Nigeria. As a commercial or cash crop, maize's production and sale for commercial purposes is dominated by men. Women farmers often view maize production as a productive, income-generating activity, yet refrain from growing maize because they lack the capital to purchase the required inputs, like fertiliser, or hire someone to plough the fields. Instead, they cultivate maize on a limited scale and continue growing other crops like cowpea, groundnuts, cassava, and yams, which require fewer fertiliser inputs. In some instances, especially among spouses, men take over control of women's maize crop as it is commercialised. As a result, women who grow maize, mainly do so for household food security.

There are several implications of these findings for the further development of the MVC. As shown, political interest in the value chain has puts smallholder farmers at a disadvantage. Thus, the politics behind the implementation of Nigeria's fertiliser subsidy policy remain an issue that needs better reconsideration, as the movement of subsidised fertiliser from the public to the private sector sabotages the government's efforts to support smallholder maize farmers. On average, the fertiliser subsidy policy tends to have a more significant impact on total fertiliser use when administered in areas where the private sector has been inactive. This is because the initial level of fertiliser use in such areas is low compared to areas where the private sector is active. To promote and enhance the commercialisation of the MVC in Nigeria, the government should therefore provide a conducive environment for the private sector to play a role in the procurement and distribution of agricultural inputs. At the same time, the government should maintain its position in quality control and the enforcement of policy implementation. 
This paper examines the political economy of the MVC in Nigeria to better understand the constraints and opportunities for agricultural commercialisation in the country. The study was carried out under the Agricultural Policy Research in Africa (APRA) programme. A political economy framework is used to illuminate how groups in society compete for and use resources, rents and power to advance their interests. Maize was chosen as the focus of the study, not only because it is the third most important cereal in Nigeria (after sorghum and millet), but also because it has a wider range of domestic and industrial uses than either of the other main cereals. In addition, maize is a politically important crop in Nigeria because its domestic demand far outstrips its supply (by about 2 million $t$ per year). There is an increasing demand for maize in the country, mainly because the grain is used for livestock feed (predominantly poultry) and serves as the primary food for the growing population (Ogunniyi 2011). Thus, the production and trade of maize attracts many stakeholders' political interests, including political elites, policy makers, industrial processors, and traders. The high demand for maize products largely motivates the interest in multiple maize uses, such as food, feed, and industrial raw material (BaduApraku and Fokorede 2017).

The strategic importance of maize in Nigeria is further amplified by its role as a source of foreign exchange. Beyond serving as a source of food for humans and livestock and as a source of foreign exchange, maize has multiple alternative uses. This includes the edible oil extracted from maize seeds, which is used as an allpurpose culinary oil. Levulinc acid, a chemical derived from maize, is used as an anti-freeze ingredient, and can replace toxic petroleum-based ingredients. Ethanol obtained from maize is used as a biomass fuel. Maize straw is a cheap source of energy in homeheating furnaces. Maize is also useful in medicines and as a raw material for industries. Due to the competing uses of maize, by both humans and livestock, there is a need to increase its supply level. Studies in maize production in different parts of Nigeria have shown the increasing importance of the crop amidst its growing utilisation by food processing and livestock feed mills (Abdulrahman and Kolawole 2008; Ogunsumi, Samuel and Adebiyi 2005). Maize has, thus, grown to be a local 'cash crop', most prominently in the southwest of Nigeria, where at least 30 per cent of cropland has been allocated to maize production. Growing maize in farms of 1-2 ha can overcome hunger in a household, and the aggregate effect could double food production in Africa (Oladejo and Adetunji 2012).

The starting point for this study is based on the need for a comprehensive understanding of the challenges facing the MVCs in Nigeria in order to help promote equitable strategies for commercialisation. Using a political economy framework, three key questions are addressed: (1) the key actors and interests: who participates and how do they benefit? (2) Rules and policies: who makes the rules, and who wins and loses? And (3), what are the implications across different social groups? The framework situates development initiatives within an understanding of the prevailing political and economic processes in society, specifically, the incentives, relationships and distribution and contestation of power between different groups and individuals (Tolentino 2010).

The results of this study show, first, that the political interest in the MVC is largely focused on the fertiliser inputs required in maize production, as different actors tend to benefit from the diversion of government subsidised fertiliser for their own gain. The private sector processing industries and traders prefer to import maize because they profit from the relatively lower prices compared to domestically produced maize. Second, these political interests in the MVC have implications for production and marketing, especially for smallholder farmers who are often disadvantaged. This is an issue of particular concern because maize is a staple food for an estimated 40 per cent of the population. Nigerians consume maize as a starchy base in a wide variety of food recipes, thus, it plays an important role in filling the hunger gap after the dry season. With the private sector preferring to import maize than to purchase it locally, the government imposes export bans from time to time to protect domestic consumers. The government attempts to limit the importation of maize through the issuance of licences that are tightly controlled. Most of the people 
who are able to get the licenses are closely connected to politicians or are themselves politicians.

A third finding is that the social differentiation between men and women has direct implications for the prospects for commercialisation of the MVC in Nigeria. As a commercial or cash crop, Maize's production and sale for commercial purposes is dominated by men. Women farmers often view maize production as a productive, income-generating activity, yet refrain from growing maize because they lack the capital to purchase the required inputs, like fertiliser, or hire someone to plough the fields. Instead, they cultivate maize on a limited scale and continue growing other crops like cowpea, groundnuts, cassava, and yams, which require fewer fertiliser inputs. In some instances, especially among spouses, men take over control of women's maize crop as it is commercialised. As a result, women who grow maize, mainly do so for household food security.

The paper concludes that the combination of the apparent capture of fertiliser subsidies by the private sector and the importation of cheaper maize from outside Nigeria have significant negative effects on attempts to commercialise the MVC. Smallholder farmers find it particularly difficult to engage in meaningful commercial production of maize, even though successive governments have attempted to propagate supportive policy environments for this to happen. The commercialisation of the MVC could serve as an incentive for agricultural households to increase their present level of maize supply to bridge the gap between production and consumption.

The challenges that the MVC in Nigeria grapples with make it very difficult for Nigeria to bridge the current deficit between domestic production and demand, yet the land that is committed to the production of maize annually has the potential to produce adequate maize to meet Nigeria's demand, without having to resort to imports. Addressing obstacles that negatively affect the MVC would, inter alia, serve as an incentive for smallholder famers to ratchet their present maize production to levels that would make Nigeria selfsufficient in maize production to the extent of even huge surpluses for export.

The paper is divided into seven sections. Following this introduction, Section 2 presents the methodology that was used to carry out the study. Section 3 sets the context for understanding and analysing the political economy of the MVC in Nigeria by briefly examining the policy terrain in both historical and contemporary context. This section pays particular attention to key agricultural policies that have shaped both constraints and opportunities in the MVC, as well as the general influence of the politics of policy making. Section 4 presents an overview of the MVC in Nigeria, with particular focus on how it has performed between 2010 and 2019 and the drivers behind its performance. Section 5 undertakes a detailed mapping of the MVC, outlining its key stages and including an analysis of the impact of the COVID-19 pandemic. Section 6 details the social differentiation processes in the MVC, resulting from different contextual issues and policies, with particular focus on gendered impacts and outcomes. Section 7 makes some concluding reflections. 


\section{METHODOLOGY AND DATA SOURCES}

The study employed a mixed-methods approach (combining qualitative and quantitative tools and techniques) in terms of data collection and analysis. The operationalisation of both qualitative and quantitative methods of data collection was informed by a detailed value chain mapping, which is deemed critical to understanding the politics of the MVC in Nigeria. Value chain mapping examines the different maize markets and their requirements, by among other methods, drawing a visual representation of the MVC. The MVC involves various linkages between maize growers, the input and logistical service providers, transporters, traders, and retailers. Value chain mapping provides a descriptive structure that is useful for data generation and analysis. It often results in developing a tree-like diagram showing the interconnectedness of various actors or their input-output relationships. Value chain mapping also involves market margin analysis, identifying value chain actors, developing an overview of product transformation, and estimating the costs arising at every stage. This greatly aids understanding of how various actors in the chain interact with one another.

Prior to the fieldwork, the researchers conducted a review of related literature, including policy, technical, and seed system study reports. The review provided some in-depth knowledge of MVC activities in Nigeria. An integral component of this study was to solicit important information from knowledgeable actors in the MVC as key informants (see Annex A for a list of the questions key informants were asked). The key informants included a mix of representatives from the private sector, government organisations, producer organisations, and research institutions. Data was collected from eight major groups of MVC actors, namely: (1) smallholder farmers, (2) commercial farmers, (3) fertiliser suppliers, (4) maize processors, (5) seed producers/companies, (6) wholesale dealers, (7) credit institutions, and (8) policy implementers (see Annex B). In selecting the key informants, researchers kept in mind what insights their responses would provide into issues of mapping the MVC, policy making, and social differences within the chain. Researchers purposely selected the actors from two States in Nigeria: Kaduna and Plateau States - the major maize producing areas in Nigeria. At least one representative was selected from each of the value chain activities. A KII guide was used to guide discussions (see Annex C). 


\section{CONTEXTI THE POLITICAL ECONOMY OF AGRICULTURAL POLICY IN NIGERIA}

\subsection{Background and framework}

As both a staple food and a primary smallholder crop, maize plays a dominant role in many people's livelihoods in Nigeria. Therefore, identifying appropriate policies in the maize sector offers substantial opportunities to improve the welfare of people. However, policy change in the maize sector rarely comes easily. Maize sector policies are often closely aligned with entrenched political-economic networks' interests, which can stymie efforts towards policy reform (Poulton and Kanyinga 2014; Jayne et al. 2002). Challenges associated with achieving reforms to maize sector policies are highlighted by the often sharp divergence between government commitments to market liberalisation, on the one hand, and the maintenance or expansion of substantial state involvement in the maize sector, on the other hand (Kherallah et al. 2002).

There are three ways governments in Nigeria typically intervene in the maize sector to achieve political and developmental objectives. The first is through output market interventions, which include using marketing boards to support high farm gate prices for smallholder farmers and to lower consumer prices through subsidised sales of government stocks, as was the case in 1977 (Barrett and Mutambatsere 2008, Ikpi, 2000). The second is through input subsidy support, mainly for maize seed and fertiliser, as was the case in 1975, when fertiliser procurement and distribution was centralised. As a result of this centralisation, all fertiliser procurement and distribution activities in Nigeria were effectively taken over by the federal government (Jayne and Rashid 2013; Ikpi, 2000). Finally, the Nigerian government regularly uses trade policy levers, including tariffs, export bans, licenses, and quotas, to regulate maize supplies and prices, as seen in Nigeria's border closure and policy ban on maize imports in 2019 and the removal of the ban in 2020.

For more than a decade, it was thought that increasing food imports would address the nation's food shortage problem. However, it has become obvious that rather than bringing solutions, such a measure has fuelled inflation, discouraged local production, created poverty among many farm households, and helped to cause food insecurity. This therefore necessitated alternative policy actions (Manyong, et. al. 2003). Much effort has been geared towards increasing the availability and adoption of improved technologies in maize production in Nigeria, both at the national and State levels. Specifically, in 2006, the federal government initiated a programme of doubling maize production in Nigeria through promotion of improved production technologies, such as fertiliser, hybrid seeds, pesticides, herbicides, and better management practices. Several improved maize varieties that are drought tolerant, tolerant of low nitrogen, Striga tolerant, stemborer resistant, and early maturing have been deployed to increase production by resourcepoor maize farmers.

Increased public investments in input subsidies, combined with greater political attention on maize selfsufficiency as a prominent policy objective in Nigeria has contributed to the use of trade restrictions on maize as a policy tool. In addition to contributing to deficits and food price spikes, ad hoc bans on private cross border trade can serve as valuable patronage tools; since such restrictions enable well placed trading firms to generate rents through asymmetric knowledge of the government's intended actions in terms of trade. Birner and Resnick (2010) draw a political economy framework that emphasises critical variables, which influence smallholder agricultural policy making, as follows:

1. Interest groups and collective action: this variable draws attention to the relative political power of urban and rural constituencies in terms of the ability to organise themselves as well as to exert political pressure. This variable can help to explain the policy influence of urban over rural groups, and in particular the constraints faced by rural smallholder farmers in the food crop sector in influencing policy, and the policy favouritism for elite rural large scale farmers represented by lobbying groups.

2. Interaction of voters and interest groups with politicians: this variable generally assumes politicians choose policies that maximise their chances of retaining power. An essential element 
of this is the alignment of governments' policy choices and their voting block support bases, which may include ethnic groups and urban or rural constituencies.

3. Type of political regime: this draws attention to the interplay between political regime type and the strategies deployed by the ruling party to retain power within this political structure. Intermediate variables, like the existence of multiparty elections, evidence of opposition party participation in policy making, and changes of ruling parties through competitive elections, can help to explain policy choices and their timing.

4. Ideas and ideologies: this variable draws attention to the beliefs, norms, and values that underlie, either explicitly or implicitly, policy choices. Beliefs about food security and the relative importance of the private and public sectors in achieving development objectives figure prominently in the ideological underpinnings of agricultural policy making.

5. Social mobilisation: while peasant movements have played an essential role in the Asian green revolution and land reform movements in Latin America, peasant movements have been far less politically crucial in Africa. This is perhaps due to the higher transaction costs of mobilisation in relatively lower density Africa. Urban food riots in response to domestic price spikes have been a more common feature of the African agricultural political economy. Their prevalence likely shapes the diversity of policy approaches in the region (Walton and Seddon 2008).

Nigeria's policy focus on input subsidies and trade restrictions reflects the powerful interactions between a large rural constituency, traditional authorities, and indigenous elites with investment interests in maize grain and fertiliser trade. These interactions have strengthened in the context of the maturation of multiparty politics in the country, through the distribution of private goods, such as inputs, and potentially remunerative information on the government's intentions in the area of trade policy.

\subsection{Agricultural policies in Nigeria}

Sector specific agricultural policies have been largely designed to facilitate agricultural marketing, reduce agricultural production costs, and enhance agricultural product prices as incentives for increased agricultural production. Manyong et al. (2003) identified the major policy instruments affecting maize in Nigeria as follows:

1. The Agricultural Commodity Marketing and Pricing Policy: the major instruments of the Agricultural Commodity Marketing and Pricing Policy were six national commodity boards, established in 1977 to replace the regional, multi-commodity boards that had been operating since 1954. The six new national commodity boards were for cocoa, groundnut, palm produce, cotton, rubber, and food grains. The grains marketing board was particularly unique as it represented the first effort ever made to extend the marketing board system to cover food crops. The National Grains Board handled maize, millet, sorghum, wheat, rice, and cowpeas. It administered a guaranteed minimum price policy, whereby floor prices were nationally set for each of the six grain crops at guaranteed minimum prices. This meant the Board would intervene as a buyer of last resort if and when regular market prices fell below the guaranteed minimum. The Board also operated a strategic grain reserve scheme.

2. Input supply and distribution policies: government policy on input supply and distribution focused on instruments for ensuring the adequate and orderly supply of modern inputs like fertilisers, agrochemicals, seed and seedlings, machinery and equipment, and so on. The key policy instruments adopted were as follows: first, the centralisation of fertiliser procurement and distribution in 1975. This resulted in all fertiliser procurement and distribution activities in Nigeria being effectively taken over by the federal government. The federal government also established a superphosphate fertiliser plant to reduce the country's dependence on foreign sources of fertiliser. Second, the creation of a national network of agro-service centres to facilitate the distribution of modern inputs, including the provision of tractor and farm machinery services to farmers. Third, the creation of a National Seed Service in 1972 to produce and multiply improved rice, maize, cowpea, millet, sorghum, wheat, and cassava seed.

3. Agricultural input subsidy policies: as far back as the 1950s, various regional governments in Nigeria were already subsidising the prices of key inputs, especially the prices of agro-chemicals used in the production of groundnut, cotton, cocoa, palm produce, and other export crops. In the early 1970s, input subsidy policy was centralised, and its application extended to food crops. The policy instruments adopted comprised of the following: 
i. Fertiliser subsidy: between 1976 and 1979, fertilisers were 75 per cent subsidised by the federal government. In 1980, the federal government's share was reduced to 50 per cent, while the State governments were required to absorb the remaining 25 per cent. However, the total percentage subsidy was subsequently reduced to 50 per cent in 1987.

ii. Seed subsidy: a 50 per cent or more subsidy on various improved seeds produced by the National Seed Service was introduced in 1987.

iii. Subsidy on agro-chemicals: rates of subsidy on agro-chemicals varied, but they were generally over 50 per cent in the late 1990s.

iv. Subsidy on tractor hire services: subsidies on tractor hire services, which mostly operated at the State level, ranged from about 25 per cent to about 50 per cent of the actual cost of tractor services in the late 1990s. learning

4. Agricultural Mechanization Policy: The need for a coherent agricultural mechanisation policy became very pressing in the early 1970s in view of an increasing shortage of agricultural labour that necessitated the substitution of human labour for some appropriate forms of mechanical power. In an attempt to achieve the objectives of the Agricultural Mechanization Policy, the following policy instruments were introduced in the late 1990s:

i. The operation of Tractor Hire Units by States.

ii. Liberalised import policies in respect to tractors and agricultural equipment.

iii. A massive assistance programme to help farmers with land clearing through cost subsidies.

iv. The launch of a machinery ownership scheme in 1980, under which the federal government provided half of the purchase cost of farm machinery to be owned and used by farming cooperatives or group farms.

5. Water Resources and Irrigation Policy: the major instrument of the Water Resources and Irrigation Policy was the establishment of eleven River Basin
Development Authorities in 1977, with overriding responsibility for the development of the country's land and water resources. The River Basin Development Authorities had a mandate for land preparation, development of irrigation facilities, and construction of dams, boreholes, and roads. They were also involved in the distribution of farm and fishing inputs. Under the civilian regime, between 1979 and 1983, they became the major instrument of the government's direct agricultural production through large scale mechanised farming.

6. The Agricultural Transformation Agenda (ATA): the ATA of the former President Jonathan's administration identified seven sectors as the main growth drivers during the transformation period, 2011-2015, including agriculture, water resources, solid minerals, manufacturing, oil and gas, trade and commerce, and culture and tourism. This selection was prompted by the fact that the performance in these sectors has been constrained by several challenges. Such challenges included low productivity; low levels of private sector investment; non-competitiveness; inadequate funding; shortage of skilled manpower; low investment in research and development; poor development of value chains and low value addition; a poor regulatory environment; the poor quality of goods and services and the poor state of physical infrastructure; policy instability and discontinuity; low levels of technology; paucity and poor flow of information; and the high cost of doing business. Government, thus, assumed a baseline GDP growth rate of 11.7 per cent per annum between 2011 and 2015, which translated to real and nominal GDP of about 428.6 billion and $\$ 73.2$ trillion, respectively, at the end of the programme period.

7. The Agriculture Promotion Policy (APP): the Buhari administration launched the APP mid-year in 2016. The APP, which builds on the ATA of President Jonathan's administration, is aimed at creating employment, ensuring food security, eliminating poverty, and repositioning the nation's economy. APP's strategic thrust is aimed at increased productivity, the promotion of private sector investment, and strengthening institutions, as a basis for better service delivery and development

8. The Presidential Fertiliser Initiative: this programme was informed by the need to stop the importation of fertiliser and make use of the large supply of locally available urea and limestone, which make up 65 per cent of the raw materials required for fertiliser production. The Presidential Fertiliser Initiative was based on an agreement in December 
2016 between the Nigerian federal government, the Fertiliser Producers and Suppliers Association of Nigeria, and the Moroccan government to supply Nigeria with phosphate. With funds provided by the Nigerian Sovereign Investment Authority, by 2017, 12 out of the 28 abandoned fertiliser plants became operational again. This initiative led to a drastic reduction in the cost of fertiliser. While a $50 \mathrm{~kg}$ bag of fertiliser sold for 14,000 in 2016; after the initiative was introduced, a bag of NPK fertiliser cost farmers $\$ 5,500$, as a result of the reactivated plants.

An overview of the political landscape of Nigeria brings to light that, despite the trillions of naira that the nation has sunk into the execution of these various policies and programmes, Nigeria is still dependent on the importation of maize and various classes of food to feed the population (Manyong et al. 2003). Thus, as a result of poor policy implementation, Nigeria is still dependent on food imports.

\subsection{Political influences on policy making}

Nigeria's political settlement is based on power relationships between elite members of society. The way these elites, especially politicians, relate to ordinary citizens is important for understanding the influences on Nigeria's agricultural policies, which impact the commercialisation of the MVC. Poulton and Chinsinga (2018) distinguish four basic ways politicians may seek to obtain or maintain the support of ordinary citizens, the examples they give focus on rural citizens. Firstly, politicians may seek to obtain or maintain ordinary citizens' support by creating conditions conducive to economic growth. Growth creates employment and livelihood opportunities, as well as new experiences for consumers. Voters in Africa assess governments on their performance in delivering growth, as well as on perceptions of high-level governance, just as they do elsewhere (Bratton, Bhavnani, and Chen 2011). Moreover, growth can be a much more cost-efficient way of spreading benefits to voters than distributing vast numbers of individual transfers (Kitschelt and Wilkinson 2007). The ATA is an example of how the Jonathan administration sought to obtain support from Nigerian citizens by promoting economic growth.

Secondly, politicians may seek to obtain or maintain ordinary citizens' support by making investments that benefit them directly and by delivering reliable public services to them. However, African governments' track record in making investments that benefit rural citizens and providing services to them is mixed. Public spending is an imperfect proxy for quality investment and service delivery, and agriculture is only one sector of interest to rural citizens (albeit an important one). The failure of most African governments to fulfil their spending commitments for agriculture - enacted in Maputo in 2003 and reiterated in Malabo in 2014 - is telling. To enhance growth and development along the MVC, the Nigerian government came up with specific initiatives such as easy access to finance through (i) the Nigeria Incentive-based Risk-Sharing System for Agricultural Lending (NIRSAL) and (ii) the Commercial Agriculture Credit Scheme (CACS). Varying levels of success have been achieved through these investments in Nigeria's MVC. Another remarkable initiative is investment in innovation through research institutes. Here, the International Institute of Tropical Agriculture (IITA) and other agriculture institutions focus on introducing improved maize varieties, developed through biotechnology and genetic breeding, to the local value chains.

Thirdly, politicians may seek to obtain or maintain ordinary citizens' support by distributing transfer rents to them. These can range from token handouts of cash and cheap goods at election time to formal developmental programmes, such as the agricultural input subsidies provided by the Nigerian government. Where transfers are highly discretionary, it perpetuates a system of patron-client relationships in rural areas - the inverse of empowered citizens holding elected representatives to account for their performance in service delivery. By contrast, where transfer programmes are effectively researched and appropriately targeted, they can usefully support productive activity (Devereux and Sabates-Wheeler 2004; Chinsinga and Poulton 2014). Nevertheless, on their own, rent transfers are unlikely to be effective instruments to promote smallholder agricultural commercialisation.

Finally, politicians may seek to maintain the support (active or passive) of ordinary citizens by various forms of political or social control. A soft version of this is to keep close links with opinion formers within a particular community or ethnic group - possibly involving some form of rent flows to these opinion formers - such that the political allegiance of that community or ethnic group remains with the party or regime (Poulton and Chinsinga 2018). This can be reinforced by a conspicuous presence in an area, giving credibility to the party's claims to understand the needs of the citizens there, and perhaps by campaigning rhetoric that spreads fear of the less-present alternatives. In a more autocratic variant, an expectation is created that ordinary citizens of an area will be loyal to the party or regime. Those who question this may be subjected to surveillance or denied access to land or other 
resources (e.g. government transfers or participation in donor projects). They may ultimately be arrested or worse if they openly challenge the party or regime. In Nigeria, politicians have sought to maintain the support of smallholder farmers through agricultural subsidies (especially fertilisers and improved seeds). 


\section{AN OVERVIEW OF THE MVC IN NIGERIA: EXAMINING ITS RECENT PERFORMANCE AND KEY DRIVERS}

\subsection{An overview of the MVC in Nigeria}

Gibbon (2001) described a value chain as a chain of activities where products pass through each activity, gaining some value at every stage in the chain. In other words, value chains are mechanisms that are separated by different actors, such as producers, processors, buyers, sellers, and consumers. A value chain encompasses the relationships between these actors as they move products from fields through to the end markets.

The political dimension of the MVC in Nigeria revolves around input supply, especially fertiliser; trading in maize, especially imports; and sales or supply to processing industries. These dimensions tend to have implications for other stakeholders in the value chain, especially smallholder producers, wholesalers, and retailers engaged in domestic trade.

To support production at the start of the chain, between 2011 and 2015, farmers - especially smallholders obtained inputs like seeds and fertilisers through two main avenues:

\section{- The government's Growth Enhancement} Scheme (GES) - a voucher based input subsidy programme accessed through private agro-input dealers (operating in networks or as individuals).

\section{- Out-grower schemes (or contract farming)}

Accessing inputs through the government's GES benefitted and empowered smallholder farmers to purchase quality fertiliser at subsidised rates under the ATA (2011-2015). Among other measures, the scheme encouraged the private sector to commercialise seed production and fertiliser distribution, moving away from a flat price fertiliser subsidy towards targeted support to smallholder farmers. The project drastically enhanced smallholders' access to quality inputs, which hitherto was non-existent. The objective of the GES was to provide affordable and quality agricultural inputs to farmers actively engaged in production through input price subsidies, removing the complexities associated with fertiliser distribution, and encouraging input suppliers to work with farmers to improve productivity. Consequently, smallholders spent less on agricultural inputs and were assured of quality inputs, which translated into increases in production. While the scheme helped smallholder farmers, it was a disadvantage to political elites, who benefitted from direct government procurement and distribution of fertiliser.

There are multiple levels of intermediation in the market post-production, which operate at varying scales of operation and provide different services. Smallholders sell to local traders, who buy maize for their retail stocks from farm gates, or from collection points if they are more prominent traders. As smallholders' marketable surpluses increase, they sell further downstream in the marketing chain to larger aggregators or directly to processors. Likewise, intermediaries of differing sizes serve as aggregators at different scales. Among the largest aggregators, unprocessed maize is ultimately sold directly to processors or at Dawanu market in Kano, Kano State (the largest grain market in West Africa). The largest traders and trade groups may transact as much as 10,000t of maize grain per annum (Dahlberg 2012).

There are currently only a few instances where aggregators are wholesale marketers engaged in contract farming with smallholders. The majority of these aggregators sell contracted maize to poultry feed millers (concentrated in Ibadan and Lagos areas). Overall, feed mills account for $60-70$ per cent of the maize grain processed in the country, with poultry farms consuming about 95 per cent of the feed produced (Table 4.1). Breweries purchase 10 per cent of processed maize, while millers producing branded flours for human consumption account for 20 per cent (Dahlberg 2012). Although cash payment at delivery dominates aggregator-smallholder transactions, the less common contract farming arrangements involve advanced purchase commitments and input provision by aggregators to enhance production. Prices differ to roughly reflect the intermediary services, for instance, smallholders that transport maize to a collection point will fetch a higher price than when aggregators pick up maize at the farm gate. Maize pricing is also dependent on grain quality, which is determined primarily by 
market intermediaries, like commission agents, and based mainly on grain moisture levels and cleanliness. Smallholders' price negotiating skills also have an influence on the final grain price.

\subsection{Performance of the MVC in Nigeria (2010-2019)}

\subsubsection{Production and processing}

Data from FAO Agricultural Marketing Information System (AMIS) (2020) (Table 4.2) indicates maize production has continued to rise from 7.68 million $\mathrm{t}$ in 2010-11 to about 11 million $\mathrm{t}$ in 2019-20, with yields fluctuating from $1.78 \mathrm{t} / \mathrm{ha}$ to $2.55 \mathrm{t} /$ ha between these years (peaking at 2.57t/ha in 2017-18). Despite a decline in yield and production in the 2015-16 and 2016-17 production years, production increased to 11.8 million $t$ and 11.3 million $t$ in the 2017-18 and 2018-19 production years, respectively. Increases in yield and production from 2011 through to 2018 are likely due to GES and phase two of the Maximising Agricultural Revenue and Key Enterprises in Targeted Sites (MARKETS II) initiatives, which gave farmers access to subsidised farm inputs, especially fertiliser, improved maize seeds, and support services.

\subsubsection{Categories of farmers in the MVC}

KIls with primary maize producers in the MVC reveal three categories of farmers (see Annex B): (1) the wet season farmers (the Maize Farmers' Association [MFA]); (2) the dry season farmers (the Fadama Maize Producers Association [FMPA]); and (3) commercial maize farmers (CMFs).

a) The MFA: smallholders in the MFA are only involved in production activities during the wet season (MayOctober). During the Klls, these farmers stated that, all things being equal, maize production is profitable. Farmers source their production inputs (seeds, fertiliser, pesticides) and sell their products in local markets. However, the input and product market dynamics are greatly affected by changes in government policies and regimes. MFA members attested that they had benefitted from improved access to quality fertilisers at lower prices under the ATA (2011-2015), compared to the preceding period (2007-2010). The advent of the ATA witnessed a significant reform that addressed

Table 4.1: Production, area harvested, and yield of maize in Nigeria

\begin{tabular}{|l|l|l|l|l|l|l|l|l|l|l|}
\hline Year & $\begin{array}{l}2010 \\
-11\end{array}$ & $\begin{array}{l}2011 \\
-12\end{array}$ & $\begin{array}{l}2012 \\
-13\end{array}$ & $\begin{array}{l}2013 \\
-14\end{array}$ & $\begin{array}{l}2014 \\
-15\end{array}$ & $\begin{array}{l}2015 \\
-16\end{array}$ & $\begin{array}{l}2016 \\
-17\end{array}$ & $\begin{array}{l}2017 \\
-18\end{array}$ & $\begin{array}{l}2018 \\
-19\end{array}$ & $\begin{array}{l}2019 \\
-20\end{array}$ \\
\hline $\begin{array}{l}\text { Total production } \\
\text { (million t) }\end{array}$ & 7.68 & 8.88 & 8.70 & 10.38 & 10.90 & 9.54 & 9.60 & 11.08 & 11.03 & 11.00 \\
\hline $\begin{array}{l}\text { Area harvested } \\
\text { (million ha) }\end{array}$ & 4.32 & 4.32 & 4.32 & 4.32 & 4.32 & 4.32 & 4.32 & 4.32 & 4.32 & 4.32 \\
\hline Yield (t/ha) & 1.78 & 2.06 & 2.02 & 2.41 & 2.53 & 2.21 & 2.22 & 2.57 & 2.56 & 2.55 \\
\hline
\end{tabular}

Source: NASC (2015)

Table 4.2: Supply and demand for maize in Nigeria (million t)

\begin{tabular}{|l|l|l|l|l|l|l|l|l|l|l|}
\hline National & $\mathbf{2 0 1 0}$ & $\mathbf{2 0 1 1}$ & $\mathbf{2 0 1 2}$ & $\mathbf{2 0 1 3}$ & $\mathbf{2 0 1 4}$ & $\mathbf{2 0 1 5}$ \\
$\mathbf{m a r k e t i n g ~ y e a r}$ & -11 & -12 & -13 & -14 & -15 & -16 & -17 & $\begin{array}{l}2017 \\
-18\end{array}$ & $\begin{array}{l}2018 \\
-19\end{array}$ & $\begin{array}{l}2019 \\
-20\end{array}$ \\
\hline Total supply & $\mathbf{8 . 1 2}$ & $\mathbf{9 . 4 0}$ & $\mathbf{9 . 6 4}$ & $\mathbf{1 1 . 0 7}$ & $\mathbf{1 1 . 9 5}$ & $\mathbf{1 1 . 2 4}$ & $\mathbf{1 1 . 3 2}$ & $\mathbf{1 2 . 4 6}$ & $\mathbf{1 2 . 7 3}$ & $\mathbf{1 3 . 4 0}$ \\
\hline Opening stocks & 0.34 & 0.32 & 0.75 & 0.49 & 0.85 & 1.30 & 1.19 & 0.98 & 1.30 & 2.00 \\
\hline Production & 7.68 & 8.88 & 8.70 & 10.38 & 10.90 & 9.54 & 9.60 & 11.08 & 11.03 & 11.00 \\
\hline Imports & 0.10 & 0.20 & 0.20 & 0.20 & 0.20 & 0.40 & 0.53 & 0.40 & 0.40 & 0.40 \\
\hline Total utilisation & $\mathbf{8 . 1 2}$ & $\mathbf{9 . 4 0}$ & $\mathbf{9 . 6 4}$ & $\mathbf{1 1 . 0 7}$ & $\mathbf{1 1 . 9 5}$ & $\mathbf{1 1 . 2 4}$ & $\mathbf{1 1 . 3 2}$ & $\mathbf{1 2 . 4 6}$ & $\mathbf{1 2 . 7 3}$ & $\mathbf{1 3 . 4 0}$ \\
\hline Domestic utilisation & 7.30 & 8.35 & 9.10 & 10.07 & 10.50 & 9.90 & 10.18 & 11.01 & 10.58 & 11.25 \\
\hline Food use & 5.10 & 5.35 & 5.60 & 6.37 & 6.70 & 5.90 & 6.18 & 6.31 & 6.08 & 6.25 \\
\hline Feed use & 0.70 & 1.00 & 1.50 & 1.50 & 1.50 & 2.00 & 2.00 & 2.20 & 2.00 & 2.00 \\
\hline Other uses & 1.50 & 2.00 & 2.00 & 2.20 & 2.30 & 2.00 & 2.00 & 2.50 & 2.50 & 3.00 \\
\hline Exports & 0.50 & 0.30 & 0.05 & 0.15 & 0.15 & 0.15 & 0.15 & 0.15 & 0.15 & 0.15 \\
\hline Closing stocks & 0.32 & 0.75 & 0.49 & 0.85 & 1.30 & 1.19 & 0.98 & 1.30 & 2.00 & 2.00 \\
\hline
\end{tabular}

Source: FAO AMIS, (2020) 
corruption and inefficiency in the distribution and marketing of fertiliser to smallholder farmers. As a result, the policy has improved farmers' access to and use of fertiliser (Amaza 2019). The KIls indicated that smallholder farmers have accessed agricultural inputs with relative ease under the ATA, which was introduced by the previous administration to address technology gaps. Since the ATA ended in 2015, farmers have been able to access fertiliser from the private sector free market.

b) The FMPA: smallholders in the FMPA confirmed that producing maize during the dry season (NovemberMay), using irrigation and supplementary water supply from near-by water sources (rivers, streams, wells/ wash boreholes) is more profitable compared to maize production during the wet season. KIls with FMPA established that they mainly produce maize for fresh consumption and seed production. They explained that fresh maize is in relatively high demand during the dry season, hence, prices are higher, which increases their income.

c) The CMFs: CMFs produce maize on large farms, usually over 50ha, or more. Their production is often associated with the use of improved technologies and efficient agricultural practices. For example, Baban Gona, a commercial maize farm located in Ikara local government area (LGA), Kaduna State, has 110 full-time staff and 700 contract staff. CMFs source their inputs locally from major farm inputs and fertiliser dealers in the State. CMFs often market harvested maize directly to processing industries, like Nestlé and Grand Cereals, and in local markets. Unlike smallholders, CMFs' access to inputs is not affected by government regime changes, as they tend to source their inputs in large quantities and do not rely on government subsidy policy. This is because most CMFs are politically influential individuals. Hence, they use their influence to access the required fertiliser.

Intermediaries of differing sizes operate as processors, including feed mills, breweries, food processors, and flour mills. Klls held with staff at Hybrid Feed Limited indicated that the firm engages in the production of feed for livestock and fisheries. The company has a staff capacity of 200 permanent staff and 300 casual staff. The firm sources maize grain locally from suppliers and farmers.

\subsubsection{Consumption and utilisation}

A survey by the IITA (2012) in Northern Nigeria revealed that almost all households surveyed consumed maize almost daily, reflecting its demand, availability, and affordability. According to the International Maize and Wheat Improvement Center (CIMMYT) and IITA (2010), approximately 60 per cent of the maize produced in the country is for industrial end uses (humans and livestock). FAO (2020) (Table 4.2) estimate the total utilisation of maize increased steadily between the 2010-11 and 2014-15 production years, declining in the 2015-16 and 2016-17 production years, and then increasing again in the 2017-18, 2018-19, and 201920 production years. The same trend was observed in domestic utilisation of maize for food, feed, and other uses, except in the 2015-16 production year, when maize feed consumption increased, whilst maize food consumption declined. The decline in maize food consumption in 2015-16 reflected a supply shortage of maize for human food, which was likely due to increases in feed milling operations to produce large amounts of heat-treated mash and pelleted feed for fish and poultry by Olam and Dantee farms in 2016 (Sahel Consulting 2017), and the scrapping of the GES in 2015.

\subsubsection{Marketing and trade}

Most of the maize produced in Nigeria is directed to the domestic market due to the growing demand, with a negligible part of the output formally exported (FAOSTAT 2012; Table 4.2). The development of the feed and food industries in Nigeria has increased local demand for maize. A ban on maize import and export was introduced in July 2019 to meet the growing domestic demand for maize by industrial processors, especially livestock feed producers. Findings from the KIls with smallholder farmers in the MFA, the FMPA and CMF categories indicate that they all sell their maize grains at markets and to processors locally. In the rainfall season, the price of dry maize, referred to as 'old maize', increases significantly due to lower supply. Grain merchants in northern Nigeria, who are often well-connected local politicians or businessmen, store up grain during its peak availability and sell it at higher prices to food processors and feed mills in the off-season. Fadama farmers also indicated that 'fresh maize on the cob' is in high demand in the dry season and therefore profitable. KIls with wholesale traders confirmed that they purchase maize grain from farmers in satellite and local markets and supply it to an array of food processors and feed mills after harvest (November-April). It is worth mentioning the direct entry of agents of processing companies into the markets to purchase grain immediately after harvest to compete with other buyers and reduce their costs.

Trade data for exports (Table 4.2) indicate a negligible quantity of maize exported to other countries from Nigeria. The largest export amount was 0.5 million $t$ 
in 2010-11, which declined to 0.3 million $t$ and 50,000t in 2011-12 and 2012-13, respectively. A steady export quantity of 0.15 million $t$ per annum was maintained between 2013-14 and 2019-20. In the same vein, 0.2 million $t$ of maize was imported between the 2010-11 and 2013-14 production years. The level of imports increased to 0.4 million $t$ in 2015-16, peaking in 201617 at 0.53 million $t$, before declining back to 0.4 million $t$ in 2017-18. This level of imports was maintained through to the 2019-20 production year.

Due to the growing demand for maize in the feed sector, large feed mills and poultry farms occasionally obtain import permits for purchasing foreign maize when they anticipate a significant domestic supply shortfall. However, due to the national business strategy to source maize from domestic suppliers, the Nigerian government imposes strict foreign exchange measures, making it challenging to obtain import and export permits. The underlying factors that drive the restriction of foreign exchange for imports of maize include i) to ensure supply is purchased from domestic sources and generate higher prices for smallholder farmers; and ii) to curtail the diversion of foreign exchange by importers for other profitable purposes instead of reinvestment in maize. For over a decade, Nigeria has maintained a 5 per cent tariff on imported maize, in addition to stringent import permit requirements. Despite the strict foreign exchange measures, politically well-connected business people undertake some informal regional trade. Hence, Nigeria's reported maize import and export volumes are not entirely accurate (Sahel Consulting 2017). The Dawanu market in Kano, Kano State, is the primary centre for informal maize exports.

Challenges remain in Nigeria's domestic and international trade, including the high cost of transportation, poor and sparse road networks, the long distances from farms to markets, inadequate market information to identify domestic and external opportunities, and poor infrastructure (USDA 2012). Limited understanding of key export markets (such as the EU, UK, and US) and the low quality of agricultural products has also hindered international trade.

\subsection{The drivers of the MVC in Nigeria (2010-2019)}

\subsubsection{Public sector driven land acquisition and productivity growth}

Over the years, agricultural production in Nigeria has been impacted by input challenges. Local farmers have lacked the required seedlings, fertilisers, land, and water for production activities. Additionally, the process of securing land is time consuming and expensive, which discourages agricultural activities. Political considerations often influence access to land, with political elites and politically well-connected individuals having better access to fertile land.

The significant constraints associated with Nigeria's current land use legislation include:

- The lack of existing land policies to guide land management in Nigeria. The Land Use Act introduced in 1978 did not assign any critical control over land and land management to the federal government, besides the Council of States' advisory role. The lack of a national technical body to assist and advise the Council of States has hindered it from developing the needed regulations for effective and efficient land law implementation.

- The Current Land Use Act does not encourage private sector investment in agriculture and agriculture related activities (e.g. short-term leases do not enable farmers to access agricultural loans,particularly smallholder farmers).

- The process of securing a land title is cumbersome, time consuming, and often expensive.

- The implementation of the Land Use Act has not ensured women's inclusion in agriculture, i.e. gender biases in access to land mean that women face more difficulty in accessing land than men.

- $\quad$ Land grabbing has resulted in communities being dispossessed of large areas of land (Amaza 2019).

The process of land acquisition has implications for maize production, whereby smallholder farmers can only access family land and rented or leased land to grow maize. Thus, this tends to limit the land area under cultivation. Smallholder farmers therefore have limited or no security of tenure, which limits their ability to access capital and invest in farmland.

The ATA (2011-2015) encouraged State governments to launch different initiatives to ease land acquisition for agricultural purposes. For example, Edo State subsidised land acquisition costs and eased the Certificate of Occupancy acquisition process. Similarly, in 2016 Anambra State promoted improved community relations to facilitate a conflict-free land acquisition process, while enacting the Land Acquisition Act (2016) to smoothen land transfers. 
Building on the regional momentum of the New Partnership for Africa's Development (NEPAD) (2001) and the Comprehensive Africa Agriculture Development Programme (CAADP) (2003), the ATA took measures to increase food production and to develop the agricultural sector through commercialisation. The ATA focused on addressing input challenges, which resulted in policies that facilitated the supply of subsidised seeds and fertilisers to 18 per cent of farmers in Nigeria (estimated at 12-14 million). The key stakeholders in the MVC, behind the ATA, include policy makers, research institutes, seed companies, livestock feed manufacturers, input suppliers (primarily fertiliser suppliers), and credit institutions. The implementation of ATA had a positive impact on maize production. The total output of maize grew by 19 per cent from 8.88 million $t$ in 2011 to 10.56 million $t$ in 2015. This was an improvement from the prior period, when maize output increased by 14 per cent, from 6.72 million t in 2007 to 7.68 million t in 2010 (FAO 2019).

The ATA, which was succeeded by the APP (20162020), defined agriculture as a business and one of its initiatives was to promote private sector investment in agriculture. The Agenda also encouraged the development of private sector driven marketing organisations and the promotion of the NIRSAL scheme, targeting maize as a primary value chain to be developed in the North Central region. These initiatives were activated through a three tier government structure: through the federal, State, and local governments. While the federal government provided general guidance on the ATA and macroeconomic framework, the State and local governments oversaw its implementation. Input procurement and distribution, investment in rural infrastructure, and the promotion of marketing institutions were addressed at the State level, while the local governments oversaw the local provision of infrastructure (FMARD 2010). Three initiatives under the ATA had a far-reaching impact on the MVC:

a) Price support and input subsidy measures established by the Central Bank of Nigeria (CBN) and the Bankers' Committee, and NIRSAL encouraged lending in the agricultural sector by guaranteeing that up to 75 per cent of loans were allocated to agricultural value chains, including maize. NIRSAL also insured about 50 and 75 per cent of losses incurred by large and small to medium scale farmers. Meanwhile, the GES linked smallholders to private businesses for subsidised inputs and support services.

b) The Commercial Agriculture Credit Scheme (CACS) was designed to lend at 9 per cent interest rates to entities involved in cash and food crop value chains, including maize, poultry, livestock, and aquaculture. A sum of $\$ 200$ billion (roughly US\$1.3 billion) has been allocated for the scheme, which has been extended to September 2025. The principal beneficiaries of this scheme are large scale businesses, who often double as political elites. They benefit from assured sources of maize supply, usually in the required quantities, through contract supply agreements.

c) Doubling maize production: the IITA and other research institutions in the African crop space focus on developing and introducing improved varieties to local value chains through biotechnology and genetic breeding. Their work has led to the creation of maize varieties resistant to Striga parasites, P48W01 and P48W02, known as IITA IR-Maize Hybrid 2 and IITA IR-Maize Hybrid 4, respectively. These improved maize varieties have a yielding potential of $5 t / h a$ compared to the 1t/ha yield potential of the local varieties commonly used. Findings from the Klls conducted for this study indicate that over the years, the Institute for Agricultural Research, in collaboration with IITA, has achieved remarkable strides in the development of maize technologies. Together these institutes have developed about 58 improved open pollinated varieties (OPV)/hybrid maize varieties. The significant varieties include striga and stem borer resistant maize varieties, drought-tolerant maize, pro-vitamin maize, and quality protein maize. Many of the varieties have been adopted by farmers, especially in North Central Nigeria, where commercial production takes place. The improved varieties have helped to increase the productivity of maize from an average of $1.5 \mathrm{t} /$ ha to $2.55 \mathrm{t} / \mathrm{ha}$, (see Table 4.1), just shy of the target $3 t /$ ha required to double maize production.

\subsubsection{Private sector led input delivery and farm advisory services}

The private sector in Nigeria has the potential to supply agricultural inputs in a cost effective manner. There are several private companies who have entered the fertiliser and seed business during the last few years. The agricultural or farm supply companies in various States are also involved in the distribution of inputs. The commercialisation or privatisation of these companies offer additional potential for developing private sector based distribution channels in rural areas. Hitherto, due to the public sector monopoly, all these privately owned organisations have not had an opportunity to develop the necessary skills needed for efficient marketing and market development. Nevertheless, private sector led initiatives to provide inputs and advisory services to farmers are presently emerging. Based in Kaduna 
State, Babban Gona, for example, seeks to improve the livelihoods of 1 million smallholder maize farmers. Babban Gona ('Great Farm' in Hausa) was established in 2012 as a financially sustainable and scalable agricultural enterprise co-owned by its farmers. The company provides cost-effective end-to-end services to a network of franchise farmer groups on credit repayable at the end of the season. These services include training in sustainable farming; soil analysis; crop insurance; access to storage facilities, including a warehouse receipt programme; the marketing and distribution of products; and access to credit, fertiliser, and seeds. Babban Gona operates by franchising 'farmer groups' and partnering with farmers who have 5ha under cultivation. Since Babban Gona launched in 2012, participating farmers have benefitted from a 3.5 times increase in income from their harvests (Sahel Consulting 2017).

Maize farmers in Nigeria are also gaining access to inputs and advisory services through cooperative membership. A cooperative association is described as the collaboration of people in groups that come together voluntarily to meet their common social, economic, and cultural needs and aspirations by pooling their resources and efforts together (ICA 1996). Such groups are jointly owned and democratically controlled by their members. Bakari (2016) and Ajibefun (2006) acknowledge that the act of pooling resources together to fulfil common goals could have a significant impact on productivity. The benefits of membership of such associations include higher sales bargaining power, guaranteed access to credit, the bulk purchase of farm inputs, and access to extension services. In Nigeria's MVC, membership of such groups has served as a channel through which information, extension, and technology is disseminated to farmers to help maximise yields.

\subsubsection{High local demand}

The production of maize has increased due to high local demand - particularly from the feed industry rising prices, and controlled imports. A specific driver of MVC development in Nigeria is the growth of the poultry sector, which relies on maize as the primary feed ingredient. Those engaged in poultry farming include both small and large poultry producers. The large poultry producers are often well-connected politically, and in some cases, they also own livestock feed businesses. Hence, they tend to have political influence in dictating developments in the MVC to their advantage, by influencing maize import policies, for instance. Dayntee Farms Ltd, for example, is a large commercial poultry farm located in Kwara State, which began operations in 2012. Dayntee Farms Ltd currently sells eggs, day-old chicks, and point-of-lay birds. The Fund for Agricultural Finance in Nigeria invested in Dayntee in 2016 to enable the farm to expand its production capacity amidst the rising domestic demand for animal protein. On average, Dayntee buys 170t of maize per month from farmers and traders in northern Nigeria for its feed formulation.

With feed costs maintained at their current prices, Lyddon (2019) reports that Nigeria's poultry meat consumption will increase tenfold between 2018 and 2040. This means, domestic poultry production could increase by 8 billion eggs and 100 million kg of poultry meat per annum between the same period. Additionally, Nigeria's yearly fish consumption is currently estimated at 2 million t, with over 20 per cent supplied through land-based aquaculture production. The scale of the poultry and aquaculture sectors has ensured Nigeria's animal feed sector, currently estimated at more than US\$2 billion, continues to attract significant local and foreign investment in large scale feed mill operations. The growing feed sector therefore constitutes a major market for maize grain and acts as a key driver for MVC development.

As one of the major Nigerian staples, there is also a high demand for maize for human consumption. Hence, institutions like Harvest Plus have pushed for mainstream maize bio-fortification through 'Scaling Up Bio Fortification Investment in Nigeria'. Harvest Plus' vision is to reach 1 billion people with bio-fortified foods by 2030 . Additionally, organisations like Nestlé (Golden Morn and Cerelac), flour mills (Daily Delight), NASCO (cornflakes), and AACE Foods (Soya Maize and Soso Nourish) fortify their maize products, which reach millions of people, with vitamins and minerals (Sahel Consulting 2017). The increased micronutrient content of bio-fortified maize has further increased demand for maize grain and driven MVC development.

\subsubsection{Integrating women and youth in the MVC}

Recognising the limitations facing women and youth in the MVC in Nigeria, initiatives have been developed to increase their business opportunities in commercial agriculture. These initiatives include the provision of training programmes that aim to ensure 50 and 30 per cent of actors in the MVC are women and youth, respectively (Amaza et al. 2018). For example, in 2017 the MARKETS II project established systemic approaches to facilitate and integrate youth and women into agricultural value chains (including maize). The project trained women in the use of sprayers for pesticide application and youth in the micro-processing 
of maize and other maize-based foods. To be inclusive, MARKETS II reduced the threshold requirement to participate in the project from tha to $0.5 \mathrm{ha}$, since women's and youths' access to land for production is often reliant on family members (husbands, fathers, male relatives) granting them land, rented land, or land leased from community leaders or other influential community members.

The social differentiation between men and women has an implication for the commercialisation of the MVC in Nigeria. Generally, in Africa, including Nigeria, men and women have different preferences and criteria for choosing which crops to grow (Guende 2009). Being a commercial or cash crop, maize's production and sale is dominated by men. In some instances, especially among spouses, men take over control of women's maize crop as it is commercialised (Durfeldt 2017). For these reasons, women who grow maize, mainly do so for household food security and use market sales to meet household needs. Women are unable to increase their production of maize because of the many challenges relate to non-ownership of land, lack of credit and inability to penetrate market cartels. This limits the quantity of maize available in markets in Nigeria.

The MARKET II project has improved women's and youths' employment opportunities and offered nutritious food products and food security to more households and communities (Amaza et al. 2018). In line with the global experience, Amaza et al. (2018) found that women's access to increased income results in three major changes in the family, namely: investment in other income generating activities, the ability to meet household needs (like food, education, and health care), and the creation of savings for unexpected events. 


\section{DETAILED VALUE CHAIN MAPPING: ACTORS, PROCESSES AND CHALLENGES}

\subsection{Actors and markets}

Value chain mapping involves identifying the actors, the product transformation, and the estimated costs arising at every stage of the value chain. Mapping the value chain components, the linkages, and actors can, among other benefits, facilitate a structured discussion about the opportunities and constraints that producers and other actors face, as well as what could be done to address them. Understanding the opportunities and limitations of producers within a given value chain helps to account for what is happening within the chain in that context and the factors that influence the chain's performance (Bolwig et al. 2010). Infrastructure, policies, trade agreements, access to credit, and property rights are examples of external factors that could significantly impact a value chain's performance and must be considered in value chain analysis (Stein and Barron 2017). A schematic description of the MVC actors in Nigeria is presented in Figure 5.1.

The agricultural and food marketing system performs three sets of functions: exchange functions, physical functions, and facilitating functions. Exchange functions include buying, selling, and storage; while physical functions involve the assembly, transportation, sorting, processing, and standardisation of products; and facilitative functions involve financing, risk-bearing, and market intelligence (Olukosi, Isitor and Ode 2007). Each of these functions adds value to the product and requires inputs, which result in the marketers incurring costs, such as advertising and transportation costs (Olukosi, Isitor and Ode 2007; Kohls and Uhl 1990). Agricultural marketing connects farmers to the final consumers. It is the sum of all business and economic activities that direct the flow of food items and services from producers to consumers (Ugwumba 2009; Ebong 2007). Agricultural market actors ensure that farm products are available in the correct form, time, place, and at an affordable price to meet consumers' demands (Olukosi, Isitor and Ode 2007; Reddy et al. 2008). Middlemen assemble surplus farm produce from across the locality as it is scattered over farm settlements. These middlemen end up being the greatest beneficiaries because they dictate the commodity prices in the urban areas.
Nigeria's maize market is influenced by a combination of growing domestic demand (for both human consumption and feed) and state intervention in foreign exchange, including a ban on maize imports between 2005 and 2008 and bans on maize exports at different moments in time, such as in 2009 and 2010. Since 2015, the Buhari administration's mantra to produce what it consumes and consume what it produces has led to import bans on dozens of items, including the staple food, maize. In August 2019, Nigeria unexpectedly closed all its land borders with Niger, Cameroon, and Benin, to stop all movement of goods, except oil, for import or export. The Nigeria-Benin border closure was implemented without any formal communication with government officials of neighbouring countries. The closure is part of Nigeria's economic strategy to tackle the smuggling of goods across the border, increase local production, and protect local producers, as outlined in its 2017-2020 Economic Recovery Growth Plan. Smuggling activities across the Nigerian-Benin border account for yearly losses of about $\$ 110$ billion (US\$304 million) in trade revenue (Damilola 2020). Informal cross border trade flows of maize between Nigeria and its neighbouring countries are concentrated in the Kano-Katsina-Maradi regions at the border with Niger. This corridor is characterised by flows of both local products and exports from other countries. Niger imports significant volumes of cereals, including millet, maize, and sorghum, from Nigeria to mitigate its structural production deficit.

Although domestic production has increased, farmers still struggle to produce sufficient maize for Nigeria's population of over 200 million people. The federal government has therefore promised to release 30,000t of maize from the national reserves to poultry farmers to deal with the high cost of poultry feed after the ban on maize imports. On 13 July 2020, the CBN directed all authorised dealers to discontinue the processing of Form M (a mandatory statutory document to be completed by all importers for the importation of goods into Nigeria) for the importation of maize, with immediate effect. The inconsistent circle of opening and closing the borders is an ostensible indication that some powerful governmental and non-governmental actors benefit from the system. These state actors operating in a cohort with powerful business tycoons connive to ensure the cycle continues. 


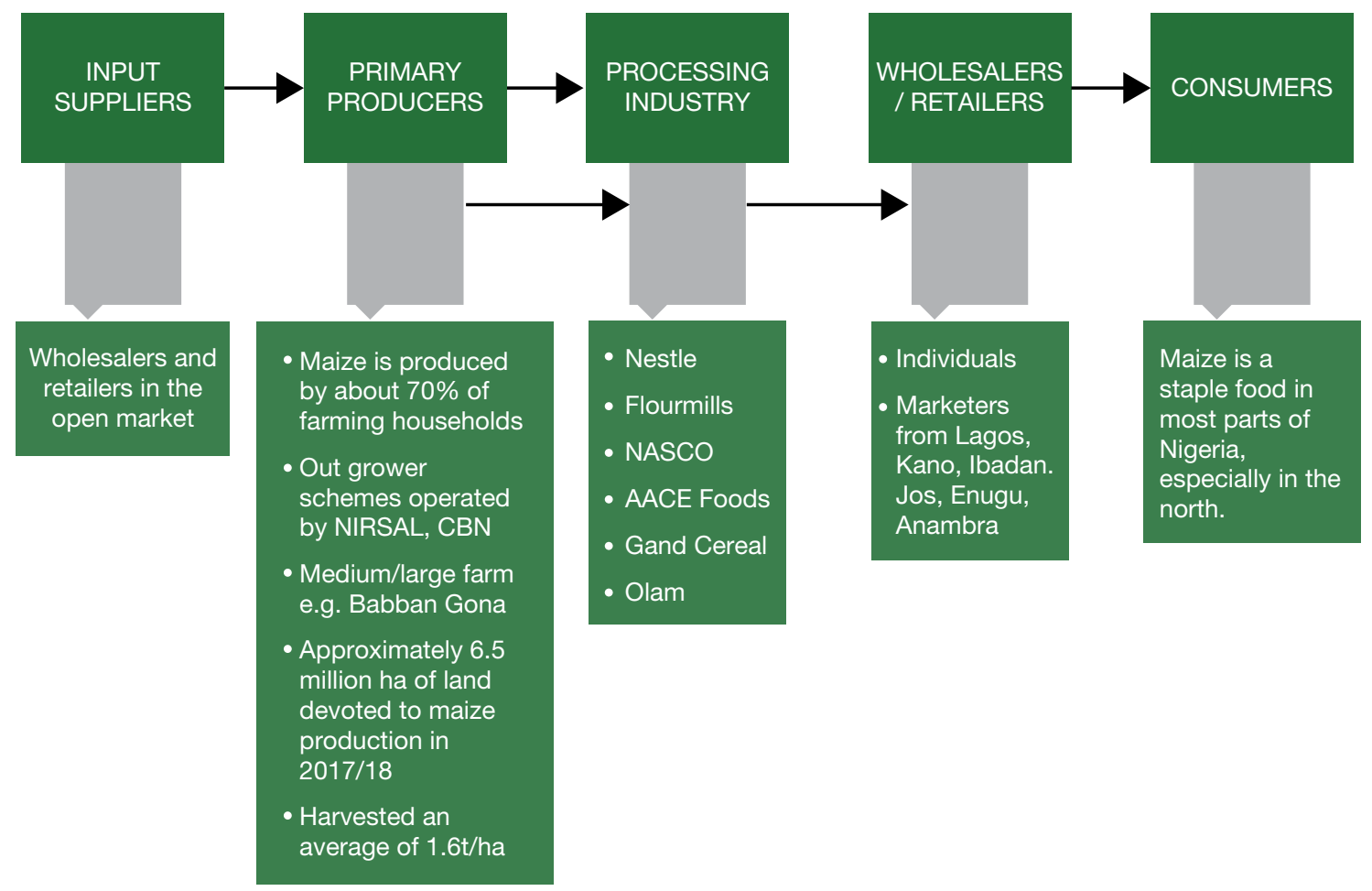

Source: Adapted from International Finance Corporation (IFC), 2019

Like many other African countries that rely on the agricultural sector for food self-sufficiency and employment generation, Nigeria has been experiencing challenges since the World Health Organization declared the COVID-19 outbreak a global pandemic on 28 February 2020. Following the federal government's shutdown directive and the restriction of movement across the country's States, agricultural production, processing, and distribution has been affected. One such area adversely affected is the production and processing of maize (Table 5.1). Farmers across the MVC, especially those operating in the poultry feed segment, have been struggling to find maize to buy. Maize has been in scarce supply since the introduction of restrictions in response to the pandemic and prices have risen on a daily basis (Table 5.2). The scarcity of maize and the continuous rise in its cost has dire consequences for poultry farmers and all sectors linked directly or indirectly to the poultry value chain.

In February 2021, about 300,000t of maize was released into the Nigerian market from strategic anchors under the Anchor Borrowers' Programme of the $\mathrm{CBN}$, which is expected to reduce the current price of maize from $\$ 155,000$ to $\$ 88,000$ per $t$ (Damilola 2020). The release of this maize follows moves made by the CBN, working with the Nigeria Customs Service (NCS), in the last quarter of 2020, to facilitate import waivers to allow four agro-processing companies to import a total of 262,000 t of maize to bridge the shortfall in local production. The release of $300,000 t$ of maize is expected to cause the price of maize in the Nigerian market to drop significantly, thereby increasing demand for the crop and ultimately enhancing the gains of maize farmers. Before the CBN-NCS collaboration, in August 2020, President Muhammadu Buhari approved the release of 30,000t of maize from the National Strategic Grain Reserve to support the Poultry Association of Nigeria at a subsidised rate. The result was a momentary stability in the price of maize.

One of the reasons feed processors import maize is because it is cheaper from some countries, like America, where the government heavily subsidises the production of maize. By the time feed processors import American maize to Nigeria, it is still relatively cheaper than domestically produced maize, due to the higher production costs for Nigerian maize farmers. American maize is also cheaper because the value chain has a higher level of technology, which means productivity is higher and it therefore costs American farmers less to produce 1t of maize. While Nigeria's maize yields peaked at 2.5t/ha, in America maize yields are 5.6t/ha, and even higher in some cases. 
Table 5.1: Changes in the amount of maize purchased before and after lockdown/COVID-19 among selected MVC actors in Nigeria*

\begin{tabular}{|l|l|l|l|l|}
\hline Value chain actor & $\begin{array}{l}\text { Frequency of } \\
\text { supply }\end{array}$ & $\begin{array}{l}\text { Quantity sourced } \\
\text { before lockdown// } \\
\text { cov/D-19 (t) }\end{array}$ & $\begin{array}{l}\text { Quantity sourced } \\
\text { post lockdown/ } \\
\text { covlD-19 (t) }\end{array}$ & $\begin{array}{l}\text { Percentage } \\
\text { change (\%) }\end{array}$ \\
\hline Fertiliser supplier & Weekly & 60 & 15 & -75.0 \\
\hline Agrochemical supplier & Weekly & 1,500 & 500 & -66.7 \\
\hline Processor & Weekly & 35 & 24 & -31.4 \\
\hline Processor & Weekly & 20 & 5 & -75.0 \\
\hline Processor & Weekly & 5 & 4 & -20.0 \\
\hline Processor & Weekly & 50 & 40 & -20.0 \\
\hline Wholesaler/retailer & Weekly & 10 & 4 & -60.0 \\
\hline Wholesaler/retailer & Weekly & 3 & 1.5 & -50.0 \\
\hline Wholesaler & Weekly & 6.5 & 3 & -53.8 \\
\hline Wholesaler & Weekly & 10 & 5 & -50.0 \\
\hline Wholesaler/retailer & Weekly & 2 & 1 & -50.0 \\
\hline Average & & & & -50.2 \\
\hline
\end{tabular}

Source: Authors' field survey, 2020

*Before lockdown refers to quantities sourced before 31 March 2020, while after lockdown refers to quantities sourced after 1 April 2020.

Table 5.2: Changes in the prices of maize grain as a result of lockdown/COVID-19 among selected MVC actors in Nigeria

\begin{tabular}{|l|l|l|l|l|}
\hline Value chain actor & $\begin{array}{l}\text { Frequency of } \\
\text { supply }\end{array}$ & $\begin{array}{l}\text { Price of maize } \\
\text { before lockdown/ } \\
\text { cov/D-19 (N/t) }\end{array}$ & $\begin{array}{l}\text { Price of maize } \\
\text { post lockdown/ } \\
\text { cov/D-19 (N/t) }\end{array}$ & $\begin{array}{l}\text { Percentage } \\
\text { change (\%) }\end{array}$ \\
\hline Fertiliser supplier & Weekly & $5,000,000$ & $2,500,000$ & -50.0 \\
\hline Agrochemical supplier & Weekly & 500,000 & 50,000 & -90.0 \\
\hline Processor & Weekly & 80,000 & 110,000 & 37.5 \\
\hline Processor & Weekly & 80,000 & 110,000 & 37.5 \\
\hline Processor & Weekly & 80,000 & 110,000 & 37.5 \\
\hline Processor & Weekly & 90,000 & 150,000 & 66.7 \\
\hline Wholesaler/retailer & Weekly & 100,000 & 160,000 & 60.0 \\
\hline Wholesaler/retailer & Weekly & 90,000 & 115,000 & 27.8 \\
\hline Wholesaler & Weekly & 95,000 & 120,000 & 26.3 \\
\hline Wholesaler & Weekly & 90,000 & 100,000 & 11.1 \\
\hline Wholesaler/retailer & Weekly & 85,000 & 120,000 & 41.2 \\
\hline Average & & & & $\mathbf{3 8 . 4}$ \\
\hline
\end{tabular}

Source: Authors' field survey, 2020 


\subsection{Different stages and processes in} the chain

The MVC consists of many activities, namely: growing, processing, and marketing. Each of these steps in the chain have both upstream and downstream linkages. Upstream activities consist of the chain's supply side, and downstream activities are the marketing and distribution side of the chain. Seeds, fertilisers, labour, and farm technology are the essential upstream linkages at the farmer level. Meanwhile, post-harvest management, and the grading and marketing of raw maize are the upstream linkages. Value addition at the farmer level depends on input cost, output value, and the productivity of maize (Mutyasira 2019). The production and returns on investment at the farmer level depend on upstream and downstream activities, such as the scale of production and the level of technology, which helps to minimise production and processing costs.

Another critical stage in the MVC is the processing of raw maize into different maize and maize derived products. Maize processing consists of primary, secondary, and tertiary processing. At the primary processing stage, maize is graded and packed for quality and variety. The market value of the raw maize is determined at this stage. Therefore, the potential to commercialise maize processing largely depends on the quality and quantity of maize grown by farmers. Both farmers and traders undertake primary processing. Poultry and animal feed manufacturers use primary processed maize. Secondary processing involves converting raw maize into different products and by-products that are used in tertiary processing for the manufacture of a variety of food and industrial products. Secondary processing is a vital activity in the MVC. Flours, flakes, and grits are products and by-products obtained from secondary processing sold in the consumer markets, bakeries, and food industries. Tertiary processing includes industries' use of starch (obtained in wet-milling operations) for food, pharmaceuticals, paper, textiles, and adhesives. In the MVC, physical and market value is added in secondary processing, which helps in the effective utilisation of farmers' maize surplus.

The MVC consists of strategic components and activities to move raw maize grain from growers through to the processors and the final customers (IFC 2019). At each stage of the chain, value is added. Traders and intermediaries are the links between each stage in the chain. The supply chain facilitates the smooth functioning of value delivery through the value chain, linking both upstream and downstream activities. The efficiency and effectiveness of all actors in the chain has an impact on both upstream and downstream activities. The value addition abilities of MVC actors are interdependent and critical in the effective utilisation of farmers' maize surplus. Both the primary and secondary processing stages support the farmers by offering a better price compared to unprocessed maize. These processing stages are essential for providing quality products for tertiary food processing units (including starch, oil high fructose, corn sweetener, ethanol, cereal and alkaline).

\subsection{Challenges affecting the commercialisation and competitiveness of the MVC}

The paramount technical constraints affecting the commercialisation of maize include access to inputs by farmers (improved seeds and fertiliser), access to credit by farmers and processors, and factors associated with climate change.

\subsubsection{Access to inputs}

The lowering of input prices through subsidies provides incentives for farmers to use more inputs, which translates into increased output (Foresight, 2011) and higher farm profit (Liverpool-Tasie et al. 2017). Subsidised agricultural inputs may include improved seeds, fertilisers, crop protection chemicals, machinery, irrigation, and knowledge. However, Farmers' access to inputs is negatively impacted by informal cross border trade and political influences on input subsidy policies, which limits the commercialisation of the MVC.

Studies undertaken by the Organisation for Economic Co-operation and Development (OECD) highlight new patterns of informal cross border trade in the West Africa region, which are not only confined to border areas, but have extended to the whole national territory of countries (Sahel and West Africa Club/OECD 2006). Nigeria plays a significant role in this informal trade with flows of petrol, grain, and fertiliser, which penetrate the northern and western parts of Niger, being reexported to Mali, Burkina Faso, and Ghana (Senahoun 2008). Informal exports to francophone countries are attributed to the informal exchange rate between the Naira and the CFA Franc, which cause Nigerian goods to be cheaper than those produced in francophone countries. The re-allocation and smuggling of subsidised fertilisers and other subsidised inputs from Nigeria can be a constraint for development initiatives seeking to increase agricultural productivity in Nigeria (Senahoun 2008). The significant volumes of maize and inputs traded informally between Niger and Nigeria imply the involvement of small and large traders, who 
take indirect advantage of the non-tariff measures (like bribes) and roadblocks. However, these informal border measures result in low-profit margins for the smaller traders (Sahel and West Africa Club/OECD 2006). This impacts Nigeria's MVC by increasing the scarcity of maize and fertiliser.

Historically, SSA governments have intervened in agricultural markets to consolidate power among largely agrarian populations (Holmén 2005). Politically well-connected agents or communities have been known to receive more input subsidies or credit than less connected individuals (Mason, Jayne, and Van de Walle 2013; Chinsinga 2012; Holden and Lunduka 2012; Mpesi and Muriaas 2012; Banful 2011; Morris et al. 2007; Holmén 2005; Olayide and Idachaba 1987). Like many other SSA countries, Nigeria allocates a substantial portion of its agricultural budget to fertiliser subsidies (Liverpool-Tasie and Takeshima 2013; Mogues et al. 2012a). The cost of fertiliser subsidy programmes between 2008 and 2010 was almost US\$150 million per year: the second largest sum among major SSA countries with similar programmes (Jayne and Rashid 2013). However, due to the influence of politically wellconnected individuals within the agricultural sector, subsidised fertiliser is often allocated sub-optimally from an efficiency perspective. In Nigeria, anecdotal evidence suggests that State governors patronise their districts of origin with preferential access to resources, including subsidised fertiliser. This means that sometimes rightful beneficiaries are excluded from fertiliser subsidy programmes because they do not support or belong to the political party in power (FMARD, 2016). The inconsistent allocation of such subsidy programmes has had a negative influence on farmers' faith towards government programmes and may affect uptake of future innovations of this nature (Amurtiya et al. 2018).

Fertiliser subsidy policies in Nigeria have changed in volume, structure, and approach, reflecting power changes in government seats. The structure through which fertiliser subsidies are delivered creates room for government corruption (Grow Africa 2016). Under the present government regime in Nigeria, the aim is to build on the success of GES between 2011 and 2015 (FMARD, 2016). The ATA's GES saw the emergence of input vouchers using mobile phone technology. However, under the Federal Market Stabilization Program (FMSP), implemented in Nigeria between 1999 and 2012, federal and State governments physically distributed subsidised fertiliser. Under the FMSP, each State distributed subsidised fertiliser to farmers through various outlets, largely the Agricultural Development Project (ADP), a state-level public institution in charge of agricultural extension and other services, including input provision. No explicit targeting criteria or individual quota existed, and distribution was often ad hoc (Liverpool-Tasie and Takeshima 2013). Another key distinction of the FMSP was that commercially distributed fertiliser existed in parallel to the subsidised fertiliser. Anecdotal evidence indicates that a substantial portion of subsidised fertiliser leaked into commercial markets and was sold as unsubsidised fertiliser. The quantities initially distributed as subsidised fertiliser often accounted for a significant share of total fertiliser consumption in the country (LiverpoolTasie and Takeshima 2013). However, the amount of subsidised fertiliser received by farmers accounted for only a relatively small fraction of the intended quantity, largely due to its diversion to profiteers.

\subsubsection{The politics of fertiliser policy implementation}

The politics behind the implementation of fertiliser policies in Nigeria remain an issue that needs better consideration. The participation of the state and private sectors jointly in the fertiliser market remains a topic of concern (Liverpool-Tasie and Tekshima 2013; Fuentes, Bumb, and Johnson 2012; IFDC 2001). Figure 5.2 shows the flow of fertiliser in the market among stakeholders. On average, fertiliser subsidy policies tend to have a greater impact on total fertiliser use when administered in areas where the private sector has been inactive and when the policies target small scale farming households that cannot pay for fertiliser at market prices (Mather and Jayne 2015; Jayne and Rashid 2013; Ricker-Gilbert, Jayne and Chirwa 2011; Xu et al. 2009a,).

Considering the history of fertiliser policy in Nigeria, Nagy and Edun (2002) report that initially fertiliser policy existed solely in the States involved in the procurement and distribution of subsidised fertiliser. Nigeria only shifted to the centralised control of fertiliser procurement and distribution in the early 1980s. The implementation of the structural adjustment programme of the late 1980s led to private control of the ownership, procurement, and distribution of fertiliser in Nigeria in the 1990s. However, the private sector's failure to step up the supply to meet the demand for fertiliser in Nigeria resulted in the government reintroducing fertiliser subsidy and government participation in the country's fertiliser market. Under the FMSP, the Nigerian government directly procured and distributed subsidised fertiliser via State governments and the private sector's role was minor (Liverpool-Tasie and Takeshima 2013; Liverpool-Tasie, Auchan, and Banful 2010). In 2001, the government introduced a 35-41 per cent subsidy for fertiliser, which later fell to 21-23 


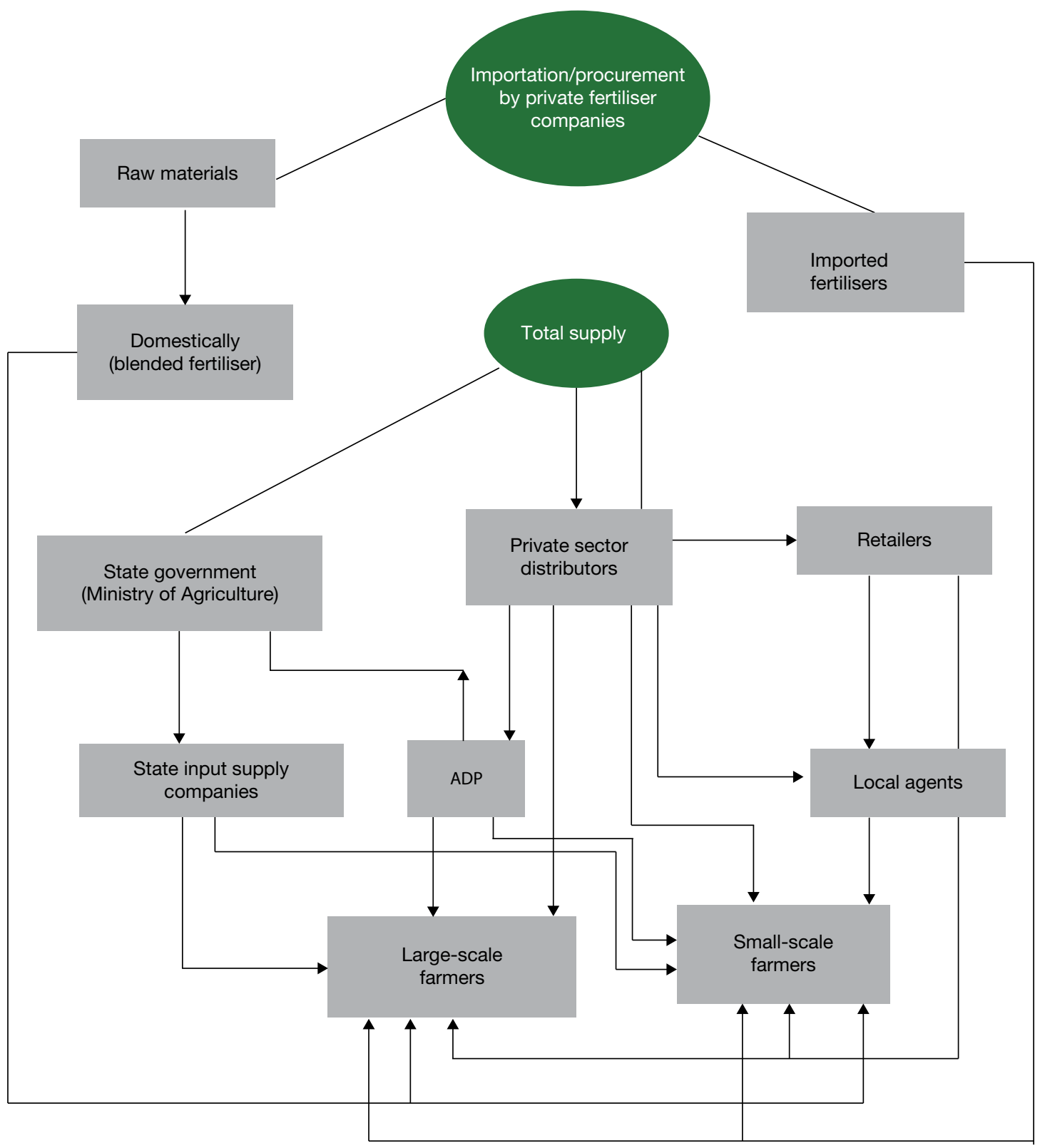

Source: IFDC (2001); Liverpool-Tasie and Takeshima (2013)

per cent, before it rose again to about 50 per cent under the GES between 2011-2015 (Amurtiya et al. 2018; Ayoola and Ayoola 2016). In 2012, farmers paid $\$ 5,500$ for two bags of fertiliser and the federal and State governments paid the balance of 50 per cent to the agro-dealers. The 50 per cent subsidy was contributed in equal proportion by the federal and State governments.

The most recent policies and programmes that encapsulate fertiliser subsidies include the ATA and the APP. As explained in the previous section, the ATA (2011-2015) used the GES to implement the fertiliser subsidy policy using mobile phone vouchers. Introduced in 2016, the APP simply aims to build on the success of the ATA, using an agribusiness approach to boost the performance of the ATA scheme. However, the politics driving the changes in this policy structure are important because this goes a long way in determining the programme's success or failure. The roles and the political power play between fertiliser policy stakeholders - including the federal and State governments, international donors and non-governmental organisations (NGOs), the Ministry of Agriculture, relevant institutions, the ADP, and fertiliser companies and importers - requires better 
understanding. Only by understanding these politics will government be able to conduct accurate scientific monitoring and evaluation to ensure the effective and efficient implementation of fertiliser policy.

The flow of fertiliser from State ministries, the private sector, and input supply companies to the ADP is worrisome and questionable. This is because, despite the numerous participants charged with fertiliser quality regulation, poor fertiliser quality remains a challenge in Nigeria. The quality challenges occur along the full spectrum of the fertiliser supply chain. Adulteration, which usually involves fertiliser being mixed with products like sand and crop or weed seeds, is a major problem. Other issues, like nutrient deficiency and underweight bags, have also been confirmed across the country (Ayoola, Chude and Abdulsalaam 2002). The fertilisers from each outlet are sold at different prices, which results in large scale and small scale farmers being exposed to fertiliser from different sources at different prices (Ayinde et al. 2019). This could result in farmers, especially small scale farmers, selling their subsidised fertiliser to agents at a higher price to obtain a short term profit instead of using the fertiliser on their fields to enhance productivity, as reported in the work of Liverpool-Tasie et al. (2015).

\subsubsection{Access to credit}

Credit has been the focus of a good deal of research work in agricultural finance. Credit is an important instrument in the development of agriculture. As emphasised by many researchers, the smallholder already caught in the vicious cycle of poverty, requires not only labour and land, but an injection of capital to extricate them from the cycle. This argument favouring credit in agricultural development is not the same as assigning it a position of primus inter pares. When a farmer is granted a loan, many other things must go with it before the loan can become a productive instrument. Apart from the fact that natural forces constrain agriculture, farmers' attitude concerning loan use is also an important factor.

Funds for agricultural finance are met through macro and microfinance mechanisms. The macrofinance aspect pertains to financing agriculture through government capital allocation to agriculture. It also includes mobilising resources for agricultural development using institutional credit agencies like the $\mathrm{CBN}$ and the Nigerian Agricultural, Cooperative, and Rural Development Bank, as well as rural banking development programmes. On the other hand, the microfinance aspect of agriculture pertains to the individual farm, in particular, the financing of farm management, which relies on the acquisition and use of capital in the farm business using commercial banks.

The federal government of Nigeria, being desperate to transform the nation's agriculture sector, has, since the early 1970s, embarked on substantial capital investment programmes in agriculture. These initiatives have been driven by the belief that credit is the allencompassing productive input required by farmers to transform their productive capacity.

Federal government funded financing and risk management strategies to support the development of the agricultural sector include the Anchor Borrowers' Programme, CACS, and the establishment of NIRSAL. The CBN's Anchor Borrowers' Programme, introduced in 2015, conceptually works like contract farming, which has been found to be effective in other developing countries like India (Bommanahalli and Rangappa, 2016). Available information from the CBN (2016) indicates that so far, under the Programme, the federal government has spent $\$ 23$ billion in promoting the local production of rice, soya bean, sugar and other important agricultural produce. The CACS was established for promoting commercial agricultural enterprises in Nigeria, which is a sub-component of the federal government's Commercial Agriculture Development Programme. The total amount released by the CBN to farmers under the CACS, since inception, stood at 635.39 billion at the end of the first quarter of 2020. In all, a total of 608 projects have benefitted from the CACS (CBN, 2020).

In line with its mandate, from its inception in 2011, NIRSAL had facilitated the investment of over 100 billion from banks and other parts of the financial sector into the agricultural sector by 2019. This was achieved by catalysing funding into various value chains from the private sector through deposit money banks, the capital market, other categories of financial institutions, vendor financiers and other value chain actors. Several State governments have also deployed funding strategies to unlock growth in their most advantageous agricultural products. All these initiatives are designed to deepen the credit market for agribusiness. For instance, according to CBN, about 74 per cent of the $\$ 200$ billion special credit intervention fund under CACS was disbursed to 191 businesses between 2009 and 2016. Forty-five per cent of the beneficiaries of this fund were involved in crop production, 23 per cent in livestock production and 15 per cent in agricultural processing. In terms of beneficiaries' location, the States with the highest number of recipients were Oyo, Kano, Kaduna, Lagos, Edo, and Kwara. 


\subsubsection{Climate change and its implications}

Climate change is a serious environmental threat to food security, and it worsens poverty due to its impact on agricultural productivity. Almost all agriculture sectors depend on the weather and climate, the increasing variability of which has meant farmers who depend on agriculture for their livelihoods may encounter total failure due to the effects of climate change (Ozor et al. 2010). Local climate variability can influence people's decisions, with consequences for their social, economic, political, and personal conditions, and can affect their lives and livelihood (Newsham et al. 2018). There is a growing consensus in the scientific literature that over the coming decades, higher temperature and changing precipitation levels caused by climate change would be unfavourable for crop growth and yield in many regions and countries, including Nigeria (Yesuf et al. 2008).

The increasing demand for maize and its global advance implies that by 2023, maize will account for the greatest share (34 per cent) of the total crop area harvested globally (OECD/FAO 2014). This estimate poses challenges to the global capacity to sustainably supply the volumes of maize needed - particularly in low- and middle-income countries. Indeed, rising demand has often driven the expansion of maize farmland in these countries and brought new land into cultivation instead of encouraging sustainable intensification to increase the yields of existing maize farms. Most of the crop production in Nigeria involves a low level of technology and is therefore heavily susceptible to environmental factors and climate change, which cause problems for farmers (Obioha 2008). The challenges facing farmers due to climate change include widespread crop failure, reduced agricultural productivity, increased hunger and malnutrition, and more frequent disease outbreaks (Zoellick 2009). These problems hamper agricultural output and the contribution of the agricultural sector to Nigeria's GDP. The number of malnourished children in SSA is expected to increase as the severity of climate change increases. Climate change models have suggested that average maize yields are likely to fall by between 5 per cent and 33 per cent by 2050, depending on the severity of climate change (Nelson et al. 2010), with the most substantial decrease in productivity occurring in the least developed countries (Ignaciuk and Mason-D'Croz 2014). At the same time, maize prices could increase by 30 per cent as supply dwindles due to climate change (Ignaciuk and MasonD'Croz 2014).

The situation of global warming is not helped by the governments in Africa. Nigeria, for example, is a mono-cultural economy in which all attempts at diversification are hindered by the indigenous capitalist class, whose sustenance is dependent on such means of production. This economic structure does not help the poor who are dependent on a few agricultural products. Nigerians find it cheaper to import maize in large quantities rather than produce it locally, probably due to the low level of mechanised farming, which hinders productivity and farmers' ability to satisfy and feed the population (Onyishi 2011). The Nigerian economy is sustained by a rentier system in which crude exploration of oil resources is the basis for revenue generation. ${ }^{1}$ Marxian literature (Onyishi 2011) does not esteem Nigeria's economic setting as productive, since the creative energy (the science behind the production) is wielded by foreign expertise. The Nigerians only control and do not even own the production tools of their oil industry (Ashley 2011). Nigeria can be said to be entirely dependent on developed economies and only have control over the means of production of agricultural crops (Onyishi 2011). This already fragile economic structure, means that Nigeria is highly sensitive to agricultural challenges caused by climate change.

1 Rentier capitalism is a term used to describe the belief in economic practices that facilitate the monopolisation of access to any kind of property (physical, financial, intellectual, etc.) and the gaining of significant profits without contributing to society. APRA 


\section{THE MVC POLICY OUTCOMES AND SOCIAL DIFFERENCE}

Building on the regional momentum of NEPAD (2001) and CAADP (2003), the overall thrust of Nigerian policy decisions and measures is to increase food production and commercialisation and develop the agribusiness sector, including the MVC. The reasons for low productivity in Nigeria include poor infrastructure, which plagues processing and marketing activities; limited farm inputs; low investment; and unfavourable government policies. Several initiatives have been launched by the national government to address these challenges. However, they have not achieved selfsufficiency in maize production as desired.

\subsection{Major changes in policy}

Nigeria has focused on four major policies or policy areas that are relevant to the MVC over the past 12 years: (1) the National Policy on Food Security (NPFS), (2) agricultural inputs policy, (3) improving access to quality seeds, and (4) agro-processing/value addition.

\subsubsection{The National Policy on Food Security (2008- 2011)}

The NPFS was launched in 2008 and focused on enhancing crop value chains to increase food production (Amaza 2019). The NPFS' main objective was to ensure that all Nigerians attain food security. Hence, the policy sought to explicitly facilitate access to high quality, locally produced food and transform Nigeria from a food importer to a net food exporter. An integral component of the NPFS was the establishment of the National Fadama Development Project (NFDP) to guarantee the growing of crops all year round and boost agricultural production through irrigation. The NFDP promoted simple, improved, and cost-effective irrigation methods with support from the World Bank and taking advantage of the various water bodies' economic potential under the River Basin Development Authority.

The principal beneficiaries of the NPFS were smallholder farmers, especially under the NFDP. For instance, in North East Nigeria, 32 per cent of farmers benefitted from increased access to agricultural advisory services, an increase in crop yields by 47 per cent, and an increase in household incomes by 40 per cent (Nkonya et al. 2019).

A main component of the NPFS and NFDP was the FADAMA III Project, established in 2008. The Project had a significant impact on the yields of maize and rice, but not on the yields of sorghum or millet (Nkonya et al. 2019). Maize yields increased by 20 per cent and production increased by 24,000t per annum-illustrating the successful promotion of higher crop productivity, which contributed to increasing food security (Nkonya et al. 2017). The increase in yields of maize and rice was due to the adoption of improved varieties and the increased use of fertiliser. The Project data revealed that, on average, household income among FADAMA II beneficiaries increased by 53 per cent - well above the Project's target of increasing revenues by 40 per cent for 70 per cent of the beneficiaries.

The NPFS made modest progress in increasing agricultural production, as maize yields increased by 20 per cent, rice by 40 per cent, and cocoa by 15 per cent between the years 2007 and 2010 (FAOSTAT, 2019). Despite the progress in aggregate production, food security remains a challenge in Nigeria, the proportion of the total population who were undernourished increased marginally from 6 to 6.2 per cent between 2007 and 2010.

\subsubsection{Agricultural inputs policy (fertiliser)}

The limited availability of inputs has impacted Nigeria's agricultural production over the years. Local farmers have lacked the required seeds, fertilisers, and water for production activities. The ATA focused on addressing this input challenge, resulting in policies that facilitated the supply of subsidised seeds and fertilisers to 18 per cent of farmers in Nigeria (estimated at 12-14 million individuals) between 2011 and 2014 (FMARD 2014). However, the fertiliser sub-sector in Nigeria remains one of the most controversial of the input sectors. It is fraught with corruption and mismanagement, arising from government subsidies and the procurement, marketing, and distribution processes (World Bank 2014). For instance, before the ATA was launched in 2011, despite the billions of Naira spent by successive 
governments over the previous four decades, only 11 per cent of smallholder farmers had accessed subsidised fertiliser (FMARD 2014). The level of corruption in the system was huge due to the government's direct procurement and distribution of fertilisers. The system disempowered smallholder farmers, since the political elites' power as the broker enabled them to siphon off fertiliser meant for smallholder farmers.

One of the ATA's strategies was to increase smallholder farmers' access to fertiliser subsidies. Hence, the Federal Ministry of Agriculture and Rural Development (FMARD) allocated a significant share of its budget to fertiliser subsidies (Liverpool-Tasie and Takeshima 2013; Mogues et al. 2012a). To help reduce corruption, the ATA supported the acquisition of fertiliser and seeds through e-vouchers for farmers involved in the maize and rice value chains. Under the ATA, the government took steps to address technology gaps by introducing the GES in 2011. Among other measures, the scheme encouraged the private sector to commercialise the distribution of fertiliser and seed production, moving away from a flat fertiliser price subsidy toward targeted support to smallholder farmers (AGRA 2019a). The policy positively impacted maize production in Nigeria, as total maize production increased by 19 per cent, from 8.88 million $t$ in 2011 to 10.56 million $t$ in 2015 (Amaza 2019).

\subsubsection{Improved access to quality seeds}

Reforms in the seed sector started in 2002, when the federal government of Nigeria constituted a panel of experts to review the National Seed Decree of 1992 (World Bank 2014). The liberalisation of the production, marketing, and distribution of basic seed by the private sector since 1992 and the adoption of the ATA in 2011 has led to changes in the demand for and supply of improved seeds. Table 6.1 presents the trends in the domestic production of certified maize seed in Nigeria. There has been remarkable growth in the quantity of improved maize seed produced in the country. Production of hybrid maize seed and OPV seed grew by 167 per cent and 1,235 per cent, respectively, over the period 2007-2017. This growth in production of improved seeds is attributed mainly to the ATA seed policy. The ATA stopped the direct procurement of improved seeds by government officials, which was associated with corruption and rent-seeking. This led to the liberalisation of foundation seed production, facilitating the growth of private sector seed producers and seed companies. Data from the National Agricultural Seed Council (NASC) (2015) showed that the quantity of foundation seed produced increased by 406 per cent from 593t in 2011 to 3,001 in 2015 . The quantity of foundation seed produced by National Agricultural Research Institutes also increased remarkably by 1,761 per cent within the same period. This increase in the production of foundation and certified seeds has increased access to improved seeds by farmers.

The seed industry's ATA policy reforms led to a growth in the number of seed companies involved in seed production from less than 20 in 2009 to 116 in 2015 (NASC 2015). The reforms promoted the private sector's leading role in Nigeria's seed industry. The rate of increase in certified seeds was highest for maize compared to any other crop, which facilitated an increase in the output of maize grain by 42 per cent between 2010/2011 and 2014/2015 (Table 4.1). A recent study conducted by the United States Agency for International Development (USAID) (2018) also revealed that farmers in Nigeria had experienced productivity increases in crop production between 2012 and 2016. The productivity increases were highest for maize farmers, who experienced a 216 per cent increase in productivity, from an average yield of $1.36 \mathrm{t} / \mathrm{ha}$ to an average yield of $4.3 \mathrm{t} / \mathrm{ha}$, as a result of the MARKETS II intervention.

The increases in production due to improved seeds have implications for farmers' food security and

Table 6.1: Trends in certified maize seed production by type and year

\begin{tabular}{|l|l|l|l|l|l|l|l|l|l|l|l|}
\hline Crop & $\mathbf{2 0 0 7}$ & 2008 & 2009 & $\mathbf{2 0 1 0}$ & $\mathbf{2 0 1 1}$ & $\mathbf{2 0 1 2}$ & $\mathbf{2 0 1 3}$ & $\mathbf{2 0 1 4}$ & 2015 & $\mathbf{2 0 1 6}$ & $\mathbf{2 0 1 7}$ \\
\hline $\begin{array}{l}\text { Maize } \\
\text { hybrid (t) }\end{array}$ & 1,137 & 2,641 & 3,150 & 1,607 & 1,947 & 3,335 & 4,639 & 2,936 & 3,143 & 3,470 & 3,033 \\
\hline $\begin{array}{l}\text { Maize } \\
\text { OPV (t) }\end{array}$ & 2,186 & 4,567 & 1,781 & 1,804 & 3,366 & 10,915 & 53,489 & 71,145 & 44,668 & 34,170 & 29,174 \\
\hline $\begin{array}{l}\text { Total } \\
\text { maize } \\
\text { seed (t) }\end{array}$ & $\mathbf{3 , 3 2 3}$ & $\mathbf{7 , 2 0 8}$ & $\mathbf{4 , 9 3 1}$ & $\mathbf{3 , 4 1 0}$ & $\mathbf{5 , 3 1 3}$ & $\mathbf{1 4 , 2 5 1}$ & $\mathbf{5 8 , 1 2 8}$ & $\mathbf{7 4 , 0 8 1}$ & $\mathbf{4 7 , 8 1 2}$ & $\mathbf{3 7 , 6 4 0}$ & $\mathbf{3 2 , 2 0 7}$ \\
\hline
\end{tabular}

Source: NASC, 2017 
welfare. Food security is a crucial indicator of household wellbeing and includes food sources from household production and cash purchases. The expectation is that increases in yields would increase farm households' food availability and income as they sell their surplus produce. Due to the link between food insecurity and poverty (Amaza, Bila, and Iheanacho 2006), increased availability of improved seed is also likely to reduce farmers' poverty level and improve their welfare

\subsubsection{Maize value addition (processing)}

Under the ATA policy, the government promoted maize value addition and interacted with major maize and soybean processors, like Nestlé, Guinness, Animal Care, Hybrid Feeds, and Grand Cereals, to gauge their requirements. Each State in Nigeria formed six production clusters to aid access to input and output markets and devised innovation platforms (IPS) to engage actors in the value chain (FMARD 2015). The IPs fostered linkages amongst actors in the value chain, especially between the public sector (ADP) and private sector participants (farmers, marketers, and the industrial processors) under a public-private partnership arrangement.

Findings from Klls with maize processors suggest that public-private partnerships between farmers and processors, combined with MARKETS II, facilitated capacity building and contributed to positive changes in both the quantity and quality of processed products. For example, in Kaduna State, one of the participating processors, Feedtek Limited, said that the partnership with Kaduna ADP increased their visibility and exposed them to farmer groups. The partnership also raised awareness of the best farming technologies and good practices among farmer groups, contributing to increased supplies of maize grains by the farmer groups to the processors (USAID 2018). The partnership facilitated farmers' access to output markets by linking beneficiary farmer groups to maize processors, who bought harvested maize from the farmers for processing. The arrangement saved farmers time in searching for markets, helped them to obtain premium prices for their maize, and, in some cases, enhanced their ability to access cash or credit in-kind from the off-takers.

\subsection{Current policies and regulations that govern participation in the MVC}

Current policy guides and regulations that govern participation in the MVC include (1) the National Fertilizer Quality Control Act (2019) and (2) the National Agricultural Seed Act (2019).

\subsubsection{The National Fertilizer Quality Control Act} (2019)

The National Fertilizer Quality Control Act was signed into law on 16 October 2019, after 17 years of political process and advocacy from the national government, NGOs, and business entities with different interests in the fertiliser sub-sector (AGRA 2019a). The protracted legislative process hinged on the economic interests of the political elites, who benefitted from the hitherto status quo for fertiliser policy. This has harmed the MVC, as smallholder farmers, who constitute over 90 per cent of maize producers, had limited access to fertiliser and were forced to purchase poor quality fertiliser at exorbitant prices.

The Act is significant because it provides a legal foundation for setting up a competitive fertiliser industry that can supply farmers with quality products at affordable prices. Additionally, the law is particularly useful in reducing adulterated fertilisers, as there is a stiff penalty for violators of the Act. It therefore protects farmers and everyone in the fertiliser supply chain, including fertiliser manufacturers, blenders, distributors, and agro-dealers, among others, from inadvertently purchasing poor quality fertiliser.

\subsubsection{The National Agricultural Seed Act (2019)}

The National Agricultural Seed Act (2019) was an improvement of the NASC Act of 2005. The Act exists for the following reasons: (1) to promote and stimulate the development of a dependable seed industry; (2) to regulate and control the registration of released seed varieties; (3) to protect farmers from sales of poor-quality seeds; (4) to facilitate the production and marketing of high-quality seeds; and (5) to provide legal backing for official certification, sales, importation, exportation and use of seeds (NASC 2019). The Act also promotes increased private sector participation in the seed sector, in line with current agricultural seed policy towards globalisation and export trade promotion.

The National Agricultural Seed Act was an outcome of consultations with stakeholders in Nigeria's seed value chain, a crucial component of the policy and regulatory reform procedure (AGRA 2017). Accordingly, the Nigerian Agribusiness Group (NABG), with the support of the Alliance for a Green Revolution in Africa (AGRA), facilitated stakeholder consultation workshops in Abuja on 9 February 2017. Essentially, the consultative workshops sought to provide an opportunity for stakeholders to contribute to the provisions of the seed Bill being processed for enactment into law. The workshop participants included vital stakeholders from 
the government, including the FMARD, NASC, NABG, the Seed Producers' and Distributors' Association of Nigeria (SEDAN), the Fertilizer Producers' and Sellers' Association of Nigeria (FEPSAN), AGRA, agri-dealers, farmers' groups, academics, legal consultants, and the IITA. The validated seed policy document was subsequently presented to the National Assembly in a seed Bill. There was a public hearing on the Bill, which passed after the first, second, and third hearings, and through the National Assembly. Finally, the Nigerian President accented to the Seed Act in November 2019.

The National Agricultural Seed Act is the most satisfactory policy from the perspective of seed producers, who play a leading role in the multiplication, marketing, and distribution of seeds. The Seed Act provides the private sector with incentives - in the form of intellectual property rights over improved varieties and an export market for seeds in the Economic Community of West African States - to supply enough quality seed to farmers at affordable prices. Under the Bill's regulations, the government performs a regulatory role in the seed industry, consequently minimising the sale of adulterated or fake seed in the seed sector. There is a stiff penalty for those who engage in marketing fake or adulterated seeds. Finally, an ex-ante impact assessment of the regulatory seed Bill has shown that the recently approved Seed Act (2019) will have positive effects on Nigeria's economy (AGRA 2017). Major stakeholders in Nigeria's seed value chain, including the government, seed producers/companies, and smallholder farmers, all stand to gain from the implementation of the reformed seed Bill. This evidence is derived from the positive net benefits revealed by a benefit/cost ratio of 2.28 for government, 3.57 for seed producers/companies, and 1.45 for smallholder farmers over five years. The higher net positive benefit ratio of 3.57 for seed producers suggests they are the greatest beneficiaries from the implementation of the Seed Act (2019).

\subsection{The actors influencing policy decisions within the MVC}

Both state and non-state actors influence policy within the MVC, in both formal and non-formal channels, depending on where their interests lie. These actors include private sector seed companies, development partners, political elites, wholesale dealers, farmers' groups, NGOs, and farmers' associations. The primary value chain activities influenced by policy decisions are (1) input supply, (2) seed production and distribution, and (3) maize distribution and sales. The focus on these value chain activities hinges on the political power of the actors involved in each stage in influencing policy reforms in the MVC.

\subsubsection{Input supply}

The actors that influence the supply and distribution of agricultural inputs are the FEPSAN, development partners (such as AGRA), agro-dealers, and state actors. In the formal sector, FEPSAN, AGRA, agrodealers and NABG have been at the forefront in influencing the recently passed National Fertilizer Quality Control Bill (2019). Together these actors organised stakeholder advocacy activities to push for the passage of the Bill, which is targeted towards regulating the production and sale of fertiliser in Nigeria (AGRA, 2019b). AGRA also funded efforts to promote the passage of the Bill under the Micro Reforms for Africa Agribusiness programme.

The main interest of the initiators of the National Fertilizer Quality Control Bill was to facilitate farmers' access to quality fertiliser and enhance the business of fertiliser production, marketing, and distribution in the formal market. However, Klls with commercial farmers established that the significant fertiliser importers, such as political elites, also influence fertiliser supply and distribution.

\subsubsection{Agricultural seed}

In the formal seed sub-sector, the major value chain actors that influence changes in policy are the private sector seed producers, through SEDAN, NABG, and AGRA. Klls with Da All-Green Seeds reveals that the private sector seed producers represented by SEDAN, NABG and AGRA played a dominant role in ensuring the national government's approval of the revised seed Bill in 2019. The private sector's interest was to ensure the embedding of quality control and efficiency in the production, distribution, and marketing of seeds in Nigeria, which would help overcome the sale of fake or adulterated seeds that act as a disincentive to genuine seed producers. Thus, the current 2019 Seed Act is envisaged to promote competition and transparency in seed production and marketing. For the development partners, their interest was to ensure a seed industry driven by the private sector, which would promote competitiveness nationally and internationally and increase maize productivity in the long run.

\subsubsection{Maize marketing}

The Maize Wholesalers' Association and the Maize Farmers' Association have remarkably influenced the policy that deals with formal trading in maize grain. Klls with wholesalers indicate that most of the Associations' elected leaders are individuals who have political influence, hence, they easily influence policy 
changes in farmers' favour, especially large farmers. For instance, the closure of Nigeria's land borders in 2019 was influenced mainly by these associations. The farmers' interest in border closures was to earn higher domestic production prices, which hitherto were low due to illegal imports from neighbouring countries. The illegal imports through informal channels, though, are also mainly influenced by wholesalers.

\subsection{Social differences within the MVC}

This section examines social differences within the MVC. The social differences are analysed according to gender, age and experience, educational level, marital status, household size, and wealth group, among other factors. Social differences, especially at the household level, affect commercialisation of the MVC.

\subsubsection{Gender}

Gender norms still affect women, especially in the main maize producing areas in Nigeria, which has implications for their physical mobility, decision making, economic participation, resource access and control, and access to information, networks, extension services, and development opportunities. In most communities, reputational risks limit women's movement beyond their homesteads and villages and they are most often discouraged from taking risks (Silong 2017). As such, women often operate on a small scale as producers and traders. Research findings by Maize Gennovate (2017) indicate women express concern for how taking risks with their businesses may jeopardise household food security and invite scorn, ostracism, or violence.

Research findings from Ater, Aye and Daniel (2018), Osundu et al. (2014), and Ogunniyi and Omoteso (2011), report that most of the stakeholders in the MVC in Nigeria are men. While most of the men are involved in the production and marketing of maize, most of the women are engaged in post-harvest handling and processing activities. Findings by Ogunniyi and Omoteso (2011) also confirm higher productivity among male managed farms, which report better access to productive farm resources and services than female managed farms. This gender difference is interpreted as partly due to men finding it more convenient to participate in most training activities than females largely because they have less limits on their mobility which enables their effective use of modern agricultural inputs. This gender differentiation is mainly influenced by religious affiliations and sociocultural orientations especially in northern Nigeria. However, some female farmers/managers, especially those who are literate or have some form of education, have access to improved technologies and extension services. Most of the time, illiterate or uneducated women rely on men for seed purchases, technology access, extensive machine use, hiring labour, and implementing new land management practices. Hence, their use of improved technologies and ownership of farmland, machinery, and tools remains low (Maize Gennovate 2017; Silong 2018).

\subsubsection{Age and experience}

Age and experience influence farmers' adoption of maize technologies, maize productivity, and the extent of commercialisation. Findings from studies of the MVC in northern Nigeria (Sennuga, Fadiji and Thaddeus 2020; Ater, Aye and Daniel 2018; Amaza et al. 2014), report that age, in correlation with farming experience, had a significant influence on the decision making process concerning risk aversion, adoption of improved technologies, and other production related decisions. The research identifies that older farmers, with more years of farming experience, have greater influence in decision making, including when to plant and apply fertiliser to maize crop. Furthermore, age was found to have a direct bearing on the availability and mobility of farm manpower, the ease with which improved practices are adopted, and the size of the farm area cultivated by the farmer at any given time. Younger farmers were generally found to be more mobile and more receptive to new ideas and technologies compared to older farmers. Similarly, in southern Nigeria, Olalekan and Bamire (2015) reported that both age and farming experience were significant determinants of adoption of improved maize varieties. They identified the dominance of older farmers in the study areas, which has adverse implications for maize commercialisation, since maize is essentially labour-intensive and older farmers have a more limited capacity to carry out manual labour. For instance, the mean age of farmers was 43 years in Kano State and 41 years in Bauchi State (Amaza et al. 2014).

\subsubsection{Educational attainment}

The political dynamics of the MVC, especially the dynamics of small and medium sized enterprises (SMEs), is affected by education. The average urban northern trader is a substantial SME managed by an educated man. For instance, in the 2015-16 season, SMEs managed by educated men sold $300 t$ and $435 t$ of maize in the low and high seasons, respectively (Liverpool-Tasie et al. 2017).

Education enables farmers to acquire and use relevant information and utilise resources more effectively 
and efficiently. The positive influence of education on farmers' production efficiency has been confirmed by many scholars (Silong 2017; Amaza 2016; Schreinemachers et al. 2016; Anigbogu, Agbasi, and Okoli 2015; Ibitoye and Onimisi 2013). These findings report that farmers with 7-12 years of formal education are more likely to be efficient in their productive activities than those without a formal education. Scholarly reports also indicate that male farmers are often more efficient and productive than female farmers because they often have more years of formal education.

\subsubsection{Marital status}

Scholarly findings, such as Amaza (2016), report increases in maize productivity for farmers living with their spouses compared to farmers without spouses. The findings highlight the benefits derived from male and female farmers' complementary roles in maize production and value addition. Conversely, Ayoola et al. (2011) found that the effect of the marital status of women on rice productivity was negative. This research implied that women are more likely to be constrained in marriage, given their multiple domestic roles and the cultural practices of keeping married women in purdah, which prevents them from direct field production activities. Married men often manage and control the majority of agricultural production and transactions for their households or families. Depending on their agency, single and married women may manage farm holdings. Women whose husbands have moved into waged labour in cities also perform diverse non-farm activities and provide significant input into technology adoption negotiations (CGIAR Consortium Office 2015).

\subsubsection{Household size}

Household size can sometimes be an asset to actors in the agricultural value chain, in terms of available workforce/labour, all things being equal. However, often actors with large households are faced with the challenges of providing social and welfare facilities, like food, education, shelter, health care, and other living expenses for many dependants, which account for their low savings. Additionally, household members tend to consume most farm produce, leaving little surplus to sell for income (Achem et al. 2013).

\subsubsection{Access to credit}

The use of credit facilities has been advocated by Ojiako and Ogbukwe (2012) to support production because it plays an enviable role in economic transformation and rural development. Defined as the process of having control over the use of others' money, goods, and services in the present, in exchange for a promise to repay the debt at a future date (Adegeye and Dittoh 1985), credit has the potential to increase farmers' productivity, enhance food security and household income, and augment the borrower's capacity to repay credit (Ojiako and Ogbukwa 2012). Hence, credit is a crucial input for the efficiency of smallholders' operations and business expansion. The limitations of self-financing farming activity; the uncertainties associated with the levels of output; and the time lag between input acquisition, use and output realisation in agriculture justify the request for and use of farm credit (Kohansal and Mansoori 2009). Whether received in cash or input-credit, credit empowers smallholders to make timely purchases, use improved seeds, apply fertiliser and herbicides, and pay for labour services. However, many reports from Nigeria indicate poor access to credit by stakeholders involved in the agricultural sector and MVC (Silong and Gadanakis 2019; Oladejo and Adetunji 2012; Amaza, Ayuba, and Alpha 2008; Amaza, Bila, and Iheanacho 2006).

Generally, smallholder farmers have less chance of accessing credit than commercial farmers. This disadvantage is further exacerbated for women farmers, who have a lower chance of accessing credit than men. The social differentiation with regards to access to credit may largely be associated with collateral ownership. Commercial farmers and men tend to have more collateral to enable them to access credit than smallholder farmers and women, respectively. Women's lack of property ownership rights act as a major barrier to them gaining collateral.

It has been reported by Ater, Aye and Daniel (2018) that the majority of the stakeholders involved in the MVC in Nigeria are in the low to medium income group. Most of these stakeholders are smallholder farmers, wholesalers, and retail maize traders. They tend to operate on a small scale, which affects their incomes. Due to their low level of income and lack of collateral to access credit, these stakeholders do not have the required resources to invest in value addition and increase the scale of their operations (Schreinemachers et al. 2016; Anigbogu, Agbasi, and Okoli 2015).

\subsubsection{Access to storage facilities}

Storage facilities are essential for storing grain until such a time that it is disposed of or sold out. However, storage facilities are lacking in Nigeria, which has a negative implication on maize production. A large quantity of maize is at the mercy of fungal infestation and moth destruction. Klls with some farmers indicated that insufficient storage facilities limited their 
production capacity. Men often have better access to large scale storage facilities, including stores that are usually rented or hired out in the marketplace of communities, than women who often store maize in small lots using bags. Additionally, commercial farmers are more likely to have their own storage facilities compared to smallholder farmers, which puts them at a further advantage compared to smallholders. 


\section{CONCLUSIONS AND POLICY IMPLICATIONS}

This paper is an attempt at unpacking the political economy of the MVC in Nigeria. It has shown how the political dimension of the MVC in Nigeria revolves around input supply, especially fertiliser; trading in maize, especially importations; sales to processing industries; and social differentiation by gender and farm size (commercial versus smallholder farmers). These dimensions tend to have implications for stakeholders in the value chain, especially smallholder producers, wholesalers, and retailers engaged in domestic trade.

The paper has addressed three main questions. The first focused on the key actors and interests: who participates and how do they benefit? We have seen that that the political interest in the MVC is largely focused on the fertiliser inputs required in maize production, as different actors tend to benefit from the diversion of government subsidised fertiliser for their own gain. These include the political elites, policy makers, industrial processors, and traders. Notably, the political elite's interest in the MVC is mainly focused on the fertiliser inputs required in maize production, where they tend to benefit from the diversion of subsidised fertiliser from the government. Private sector processing industries and traders prefer to import maize because they profit from the relatively lower prices compared to domestically produced maize. Most smallholder farmers fail to benefit from government efforts and policies due to their poor implementation and targeting, as seen in regards to fertiliser policies.

A second aspect is the rules and policies: who makes the rules, and who wins and loses? As has been demonstrated in this paper, changes in political regimes and associated policies present a challenge to dealers' and farmers' access to fertiliser and inputs. The government's constant effort to boost and improve smallholder farmers' productivity through policies intended to aid adoption and increase fertiliser use is yet to translate into an increase in sustainable agricultural production, rural household income, and livelihood. Most smallholder farmers fail to benefit from these government efforts and policies due to their poor implementation and targeting, as observed in the government's fertiliser policy. Smallholder farmers find it particularly difficult to engage in meaningful commercial production of maize, despite attempts by successive governments to propagate supportive policy environments for this to happen. The commercialisation of the MVC could serve as an incentive for agricultural households to increase their present level of maize supply to bridge the gap between production and consumption.

And third, what are the implications across different social groups? The paper has shown that the social barriers to participation in the MVC in Nigeria are significant, with wide reaching effects for commercialisation. As a commercial or cash crop, maize's production and sale for commercial purposes is dominated by men. Women farmers often view maize production as a productive, income-generating activity, yet refrain from growing maize because they lack the capital to purchase the required inputs, like fertiliser, or hire someone to plough the fields. Instead, they cultivate maize on a limited scale and continue growing other crops like cowpea, groundnuts, cassava, and yams, which require fewer fertiliser inputs. In some instances, especially among spouses, men take over control of women's maize crop as it is commercialised. As a result, women who grow maize, mainly do so for household food security. Women are unable to increase their production of maize because of the many challenges related to non-ownership of land, lack of credit and inability to penetrate market cartels. These challenges also limit the quantity of maize available in markets in Nigeria. Like women, youth are not only faced with lack of the required collaterals to access loans for MVC, but also with challenges of non-ownership of farmland. Since this segment of the society is the largest in numerical terms, their capacity to take advantage of the opportunities in the MVC is impaired. This has concomitant effect on the quantity of maize that enters the markets and marketing systems.

Policy implications from this are first and foremost the imperative to improve smallholder maize farmers' access to fertilisers. Though the National Fertiliser Quality Control Act has been approved, there should be a policy to ensure that smallholder farmers in remotely located areas have equitable access. The movement of 
subsidised fertiliser from the public to the private sector can sabotage the government's efforts to improve smallholder productivity. On average, fertiliser subsidy policies tend to have a greater impact on total fertiliser use when administered in areas where the private sector has been inactive and when policies target small scale farming households that cannot pay for fertiliser at landing market prices. Therefore, it is recommended that the government provide a conducive environment for the private sector to play its role in the procurement and distribution of agricultural inputs, while the government maintains its position in quality control and the enforcement of policy implementation. This will enhance the commercialisation of the MVC in Nigeria.

It is also clear that the current levels of informal and unregulated cross border trade is a significant barrier to the development of the MVC. Nigeria plays a significant role in this informal trade with flows of petrol, grain, and fertiliser, which penetrate the northern and western parts of Niger, being re-exported to Mali, Burkina Faso, and Ghana. Such re-allocation and smuggling of subsidised fertilisers and other subsidised inputs from Nigeria represent a significant constraint to agricultural development. The significant volumes of maize and inputs traded informally between Niger and Nigeria imply the involvement of small and large traders, who take indirect advantage of the non-tariff measures (like bribes) and roadblocks. Therefore, a clear and consistent policy initiative should be implemented to better control this cross-border trade. 
Abass, A.B. (2013) Importance of Maize (Zea Mays) in Nigeria, Health Safety and Environment, Agriculture, Politics and Gossips, October (accessed 21 January 2018)

Abbot, J.C. (1993) 'Marketing: The Rural Poor and Sustainability', in J.C. Abbot (ed.), Agriculture and Food Marketing in Developing Countries: Selected Readings, Wallingford: CAB International/Technical Centre for Agricultural and Rural Cooperation

Abdulrahman, A.A. and Kolawole, O.M. (2008) 'Traditional Preparations and Uses of Maize in Nigeria', Ethnobotanical Leaflets 10: 201-208 (accessed 22 April 2020)

Achem, B.A.; Mohammed, B.T.; Aduba, J.J.; Muhammad-Lawal, A. and Abdulquadri, F. (2013) 'A Comparative Assessment of the Profitability of Cassava Processing Enterprises in Kwara State, Nigeria', Global Journal of Current Research 1.2: 57-61

Adams, R. (2000) The Politics of Economic Policy Reform in Developing Countries, Policy Research Working Paper 2443, Washington, DC: World Bank

Adegeye, A.J. and Dittoh, J.S. (1985) Essentials of Agricultural Economics, Ibadan: Impact Publishers

Adesoji, S.A. and Farinde, A.J. (2006) 'Socio-Economic Factors Influencing Yield of Arable Crops in Osun State, Nigeria', Asian Journal of Plant Sciences 5.4: 639-634

Adeoti, A.I.; Oluwatayo. I.B. and Soliu, O. (2014) 'Determinants of Market Participation Among Maize Producers in Oyo State, Nigeria', British Journal of Economics, Management \& Trade 4.7: 1115-1127

AfDB (2016) Feed Africa: Strategy for Agricultural Transformation in Africa 2016-2025, Abidjan: African Development Bank (accessed 9 March 2021)

AfDB (2019) Baseline Study of the African Financing Mechanism (AFM), Abidjan: African Development Bank

AGRA (2017) Micro Reforms for African Agri-business (MIRA): An Assessment of Agricultural Policy and Regulatory Constraints to Agribusiness Investment in Burkina Faso, Ethiopia, Ghana, Nigeria, and Tanzania and Kenya. Nairobi: Alliance for Green Revolution in Africa

AGRA (2019a) National Fertiliser Quality Control Bill Factbook, Nairobi: Alliance for Green Revolution in Africa (accessed 8 March 2021)

AGRA (2019b) Nigeria Fertiliser Quality Control Act 2019, Nairobi: Alliance for a Green Revolution in Africa (accessed 23 April 2020)

Ajibefun, I.A. (2006) 'Linking Socio-economic and Policy Variables to Technical Efficiency of Traditional Agricultural Production: Empirical Evidence from Nigeria', poster paper prepared for presentation at the International Association of Agricultural Economics Conference, Gold Coast, Australia, August 12-18

Akinyosoye, V.O. (2005) Government and Agriculture in Nigeria: Analysis of Policies, Programs and Administration, Lagos: Macmillan Publishers Limited 
Amaza, P. (2016) N2 Africa Borno Report, Ibadan: International Institute of Tropical Agriculture

Amaza, P. (2019) Review and Analysis of the Impact of National and Regional Agricultural Policies in Africa: Nigeria Country Report, Abidjan: African Development Bank

Amaza, P.; Ayuba K. and Alpha, K. (2008) 'Farmers' Perception, Profitability and Factors Influencing the Adoption of Improved Maize Varieties in the Guinea Savannahs of Nigeria' paper presented at the International Research on food security, Natural Resource Management and Rural Development Conference held at University of Hohenheim, Germany, October 7-9

Amaza, P.S.; Bila, Y. and Iheanacho, A.C. (2006) 'Identification of Factors that Influence the Technical Efficiency of Food Crop Production in West Africa: Empirical Evidence from Borno State, Nigeria', Journal of Agriculture and Rural Development in the Tropics and Subtropics 107.2: 137-145

Amaza, P.; Hassan, M.B.; Abdoulaye, T.; Kamara, A. and Oluoch, M. (2014) Mid-Term and Cost Benefit Study of Smallholder Farmers in Striga-Infested Maize and Cowpea Growing Areas of Northern Nigeria, Ibadan: International Institute of Tropical Agriculture

Amaza, P.; Surma, N.; Martins, O. and Rinck, D. (2018) Final Performance Evaluation Report: Maximising Agricultural Revenue and Key Enterprises in Targeted Sites (Markets II) in Nigeria, Washington DC: United States Agency for International Development.

Amurtiya, M., Giroh, D. Y., Polycarp, M. and Ashindo, Z. E. (2018) Analysis of Rural Farm Households' Access to Formal Agricultural Credit in Yola South Local Government Area, Adamawa State, Nigeria. Acta Universitatis Agriculture et Silviculture Mendelianae Brunensis, 66. 4: 947 - 954.

Anigbogu, T.U.; Agbasi, O.E. and Okoli, I.M. (2015) 'Socioeconomic Factors Influencing Agricultural Production among Cooperative Farmers in Anambra State, Nigeria', International Journal of Academic Research in Economics and Management Sciences 4.3: 43-58

Arosanyin, T. (2017) Cereal Crops in Nigeria- Prospects and Challenges in the Last Five Years, the Roles of the Government, Women and Youth, Food Farm News blog, 16 February (accessed 23 April 2020)

Ashley, M. (2011) Climate Change Adaptation in Nigeria: Key Considerations for Decision Makers, Working Paper, Abuja: KONRAD Adenauer Stifting

Asogwa, B.C. and Okwoche, V.A. (2012) 'Marketing of Agricultural Produce Among Rural Farm Households in Nigeria: The Case of Sorghum Marketing in Benue State', International Journal of Business and Social Sciences 3.13: $269-277$

Ater, P. I.; Aye, G.C. and Daniel, A. (2018) 'Analysis of Maize Value Addition among Entrepreneurs in Taraba State, Nigeria', International Journal of Environment, Agriculture and Biotechnology (IJEAB) 3.6:2011-2019, DOI:10.22161/ijeab/3.6.8 (accessed 5 April 2020)

Ayinde, O.E.; Olaoye, I.J.; Bolaji, M. and Oloyede, A.O. (2019) 'Politics in Fertilizer Subsidy Implementation and Governance Structure towards Agricultural and Economic Development in Nigeria - A Review', paper presented at the 6th African Conference of Agricultural Economists, Abuja 23-26 September

Ayoola, G. and Ayoola, J.S. (2016) 'The Transformation of Smallholder Agriculture in Africa: Lessons in Policy Experimentation and Governance from Nigeria', paper presented at Fifth International Conference of the African Association of Agricultural Economists, Addis Ababa, 23-26 September

Ayoola, G.B.; Chude, V.O. and Abdulsalaam, A.A. (2002) Toward a Fertilizer Regulatory Policy for Nigeria: An Inventorization of the Fertilizer Sector, Abuja: Federal Fertilizer Department 
Ayoola, J.B. et al. (2011) 'Socio-Economic Factors Influencing Rice Production among Male and Female Farmers in Northern Guinea Savanna Nigeria: Lessons for Promoting Gender Equity in Action Research', Agriculture and Biology Journal of North America 2.6: 1010-1014

Badu-Apraku, B. and Fakorede, M.A.B (2017) Maize in Sub-Saharan Africa: Importance and Production Constraints, in B. Badu-Apraku and M.A.B. Fakorede (eds.), Advances in Genetic Enhancement of Early and Extra-Early Maize for Sub-Saharan Africa, New York: Springer (accessed 9 March 2021)

Bakari, S. (2016) The Relationship Between Export, Import, Domestic Investment and Economic Growth in Egypt: Empirical Analysis, MPRA Paper 76627, Munich: Munich Personal RePEc Archive

Banful, A.A. (2011) 'Old Problems in the New Solutions? Politically Motivated Allocation of Program Benefits and the "New" Fertilizer Subsidies', World Development Report 39.7: 1166-1176

Barrett, C.B. (2007) 'Smallholder Market Participation: Concepts and Evidence from Eastern and Southern Africa', Food Policy 23.4: 299-317

Barrett, C.B. and Mutambatsere, E. (2008) Marketing Boards, The New Palgrave Dictionary of Economics, London: Palgrave Macmillan

Bates, R. (1981) States and Markets in Tropical Africa: The Political Basis of Agricultural Policy, Berkeley: University of California Press, Series on Social Choice and Political Economy, Berkeley.

Bates, R. and Block, S. (2009) Political Economy of Agricultural Trade Interventions in Africa, Agricultural Distortions, Working Paper 87, Washington DC: World Bank

Berhanu, K. and Poulton, C. (2014) 'The Political Economy of Agricultural Extension Policy in Ethiopia: Economic Growth and Political Control', Development Policy Review 32.2: 197-213

Birner, R. and Resnick, D. (2010) 'The Political Economy of Policies for Smallholder Agriculture' World Development 38.10: $1442-1452$

Bolwig, S.; Ponte, S.; Du Toit, A.; Riisgaard, L. and Halberg, N. (2010) 'Integrating Poverty and Environmental Concerns into Value-Chain Analysis: A Conceptual Framework', Development Policy Review 28.2: 173-194

Bommanahalli, S.B. and Rangappa, K.B. (2016) 'Impact of Contract Farming on the capital formation at the farm level: An empirical investigation in Karnataka', Indian Journal of Applied Research, 6.633: 663-666

Boone, C. (2003) Political Topographies of the African State: Territorial Authority and Institutional Choice, Cambridge: Cambridge University Press

Booth, D. and Golooba-Mutebi, F. (2014a) 'Policy for Agriculture and Horticulture in Rwanda: A Different Political Economy?', Development Policy Review 32.2: 173-196

Bratton, M.; Bhavnani, R. and Chen, T.-H. (2011) Voting Intentions in Africa: Ethnic, Economic or Partisan?, Afrobarometer Working Paper No. 127, Accra: Afrobarometer (accessed 26 June 2018)

CAADP (2003) Process and Scope of the Agriculture Programme: Comprehensive African Agricultural Development Programme, Addis Ababa: African Union

CBN (2020) Guidelines for Commercial Agricultural Credit Scheme, Abuja: Central Bank of Nigeria (CBN) and Federal Government of Nigeria

CGIAR Consortium Office (2015) CGIAR Strategy and Results Framework 2016-2030: Redefining How the CGIAR Does Business Until 2030, Montpellier: CGIAR Consortium Office 
Chinsinga, B. (2012) The Political Economy of Agricultural Policy Processes in Malawi: A Case Study of the Fertilizer Subsidy Programme, Future Agricultures Working Paper 039, Brighton: Future Agricultures Consortium (accessed 6 April 2021)

Chinsinga, B. and Poulton, C. (2014) 'Beyond Technocratic Debates: The Significance and Transience of Political Incentives in the Malawi Farm Input Subsidy Programme (FISP)', Development Policy Review 32.2: 123-150

CIMMYT and IITA (2010) Maize - Global Alliance for Improving Food Security and the Livelihoods of the Resource Poor in the Developing World, draft proposal submitted by CIMMYT and IITA to the CGIAR Consortium Board, El Batan: CGIAR Consortium Office

Coelli, T.J. and Battese, G. (1996) 'Identification of Factors Which Influence the Technical Efficiency of Indian Farmers', America Journal of Agricultural Economics 40.2: 103 - 128

Crawford, E.; Jayne, T. and Kelly, V. (2005) 'Why Promote Increased Use of Fertilizer in Africa', draft paper prepared for the World Bank Africa Region, Environmental, Rural and Social Development Unit as Part of a Project that Supports its Africa Fertilizer Strategy Review

Dahlberg (2012) Catalysing Smallholder Agricultural Finance, New York: Dalberg Global Development Advisors (accessed 20 September 2020)

Damilola, A. (2020) Nigeria's Harmful Importation Policy, Nigerian Tribune, 20 September, (accessed 6 March 2021)

D'Arcy, M. and Cornell, A. (2016) 'Devolution and Corruption in Kenya: Everyone's Turn to Eat?' African Affairs 115.459: 246-273

Devereux, S. and Sabates-Wheeler, R. (2004) Transformative Social Protection, Institute of Development Studies Working Paper 232, Brighton: Institute of Development Studies (accessed 6 March 2021)

Durfeldt, A.A. (2017) Gender and Rural Livelihoods: Agricultural Commercialization and Farm Non-Farm Diversification, APRA Working Paper WP04, Brighton: Future Agricultures Consortium (accessed 6 March 2021)

Ebong, V.O. (2007) Agribusiness Management in Developing Economy: The Nigerian Perspective, Uyo: Minder International Press

Egbetokun, O.A. and Omonona, B.T. (2012) 'Determinants of Farmers' Participation in Food Market in Ogun State', Global Journal of Science Frontier Research Agriculture and Veterinary Sciences 12.9 24-30

Faße, A.; Grote, U. and Winter, E. (2009) Value Chain Analysis and Methodologies in the Context of Environment and Trade Research, No. 429) Discussion Papers, Hanover: School of Economics and Management of the Hanover Leibniz University

Fadairo O.; Olutegbe N. and Tijani A.M. (2015) 'Attitude of Crop Farmers Towards e-Wallet Platform of the Growth Enhancement Support Scheme for Input Delivery in Oke Ogun Area of Oyo State', Journal of Agricultural Informatics16.2:62-71

FMARD (2005) Agricultural Policy for Nigeria, Abuja: Federal Ministry of Agriculture and Rural Development

FMARD (2010) National Agricultural Investment Plan (NAIP), Abuja: Federal Ministry of Agriculture and Rural Development

FMARD (2011) Agricultural Transformation Agenda (ATA): We Will Grow Nigeria's Agricultural Sector, Abuja: Federal Ministry of Agriculture and Rural Development 
FMARD (2014) Agricultural Transformation Agenda 2013 Report Score Card, Abuja: Federal Ministry of Agriculture and Rural Development

FMARD (2016) The Agriculture Promotion Policy (2016 - 2020). Building on the Successes of the ATA, Closing Key Gaps, Abuja: Federal Ministry of Agriculture and Rural Development Policy and Strategy Document for Nigeria

FAO (2017) Country Fact Sheet on Food and Agriculture Policy Trends: Socio-economic Context and Role of Agriculture, Rome: Food and Agriculture Organization of the United Nations

FAO (2018) Country Gender Assessment Series: National gender profile of agriculture and rural livelihoods NIGERIA, Abuja: Food and Agriculture Organization of the United Nations and the Commission of the Economic Community of West African States

FAO (2019) Nigeria at a Glance, Rome: Food and Agriculture Organization of United Nations (accessed 9 March 2021).

FAO (2020) Food Outlook - Biannual Report on Global Food Markets, Rome: Food and Agriculture Organization of the United Nations (accessed 2 December 2020)

FAO (2020) Agricultural Marketing Information System (AMIS) Statistics (accessed 9 March 2021)

FAOSTAT (2012) Food and Agricultural Commodities Production, Rome: Food and Agriculture Organization of the United Nations (accessed 30 March 2020)

FAOSTAT (2014) National Production Statistics Nigeria, Rome: Food and Agricultural Organization of the United Nations

FMARD (2010) ECOWAS/CAADP Process: National Agricultural Investment Plan (NAIP) (2011-2014), Abuja: Federal Ministry of Agriculture and Rural Development (FMARD) (accessed 13 March 2020)

Foresight (2011) The Future of Food and Farming: Challenges and Choices for Global Sustainability, Final Project Report, London: The Government Office for Science

Fuentes P.A.; Bumb, B. and Johnson, M. (2012) Fertilizer Markets in West Africa: The Fertilizer Supply Chain in Nigeria, Washington DC: International Fertilizer Development Center and International Food Policy Research Institute

Gibbon, P. (2001) 'Agro-Commodity Chains: An Introduction', Institute of Development Studies Bulletin, 32.3: 60-67, DOI: 10.1111/j.1759-5436.2001.mp32003007.x (accessed 10 March 2021)

Goetz, S.J. (1992) 'A Selectivity Model of Household Food Marketing Behavior in Sub-Saharan Africa', American Journal of Agricultural Economics, 74.2: 444-452

Goodwin, A. (2009) 'Research Shows that Maize Production in Nigeria can be Doubled', Modern Ghana, 12 May (accessed 13 April 2021)

Grow Africa (2016) Fertilizer Subsidy Reform Revives Nigeria's Agriculture, Abuja: Grow Africa (accessed 12 March 2021)

Guende, S. (2009) What are Women's Crops and Why? FAO Gender Insights, 12 November (accessed 11 March 2021)

Hansen, H. and Baltzer, K.T. (2011) Agricultural Input Subsidies in Sub-Saharan Africa, Copenhagen: Ministry of Foreign Affairs

Haruna, S.K. and Abdullahi, Y.M.G. (2013) 'Training of Public Agents in Nigeria and the Implications on Governments Agricultural Transformation Agenda', Journal of Agricultural Extension 17.2: 98-104 
Hawkes, C. and Ruel, M.T. (2011) 'Value Chains for Nutrition, Leveraging Agriculture for Improving Nutrition and Health', paper presented at the IFPRI 2020 International Conference, New Delhi, 10-12 February

Heinemann, E. (2002) The Role and Limitations of Producer Associations, Montpellier: European Forum for Rural Development Cooperation

Holden, S.T. and Lunduka, R. (2012) Who Benefits from Malawi's Targeted Farm Input Subsidy Program? Forum for Development Studies 40.1:1-25

Holloway, G.; Barrett, C.B. and Ehui, S. (2005) 'The Double Hurdle Model in the Presence of Fixed Costs', Journal of International Agriculture, Trade \& Development 1.1: 17-28

Holmén H. (2005) 'The State and Agricultural Intensification in Sub-Saharan Africa' in G. Djurfeldt, H. Holmen and M. Jirstrom (eds), The African Food Crisis: Lessons from the Asian Green Revolution, Wallingford: CABI Publishing

Ibitoye, S.J. and Onimisi, J.A. (2013) 'Influence of Training on Farmer's Productivity in Poultry Production in Kogi State, Nigeria', International Journal of Poultry Science 12.4: 239-244

ICA (1996) Background Paper to the Statement on the Cooperative Identity, Brussels: International Cooperative Alliance Information Centre

IFC (2013) 'Developing Competitive Fertilizer Market in Sub-Saharan Africa: Policy and Non-Policy Solutions', paper presented at the Technical Convening on Seed and Fertilizer Policy in Africa, Addis Ababa, 5-7 December

IFC (2016) Investing in Women Along Agribusiness Value Chains, Washington DC: World Bank Group

IFC (2019) Developing Private Sector Investment Opportunities in North-East Nigeria. Information for Investors, Washington DC: International Finance Corporation

IFPRI (2010) A Review of Fertilizer Policy Issues in Nigeria. Nigeria Strategy Support Program (NSSP) Working Paper No. 19, Washington DC: International Food Policy Research Institute

IFAD (2015) Cassava Factsheet - Improving Marketing Strategies in Western and Central Africa, Rome: International Fund for Agricultural Development (accessed 31 March 2016)

IFDC (2001) Agricultural Input Markets in Nigeria: An Assessment and Strategy for Development, Muscle Shoals: International Fertilizer Development Center

Ignaciuk, A. and Mason-D'Croz, D. (2014) Modelling Adaptation to Climate Change in Agriculture, OECD Food, Agriculture and Fisheries Paper No. 70, Paris: OECD Publishing

IITA (2010) Annual Report on Maize Production, Ibadan: International Institute of Tropical Agriculture

IITA (2012) Annual Report on Maize Production in Nigeria, Ibadan: International Institute of Tropical Agriculture

Ikpi, A.E. (2000) 'Nigeria's Agricultural Sector Assessment: Issues of Technology Development and Transfer', paper prepared for the United States Agency for International Development's Bureau for Africa's Office of Sustainable Development

Jayne, T. and Rashid, S. (2013) 'Input Subsidy Programs in Sub-Saharan Africa: A Synthesis of Recent Evidence', Agricultural Economics 44.6: 547-562

Jayne, T.S.; Govereh, J.; Mwanaumo, A.; Nyoro, J.K. and Chapoto, A. (2002) 'False Promise or False Premise? The Experience of Food and Input Market Reform in Eastern and Southern Africa', World Development 30.11 :1967-1985 
Jayne, T.S.; Mason, N.M.; Myers, R.J.; Ferris, J.N. and Mather, D. (2010) Patterns and Trends in Food Staples Markets in Eastern and Southern Africa: Toward the Identification of Priority Investments and Strategies for Developing Markets and Promoting Smallholder Productivity Growth, Michican: Michigan State University, Department of Agricultural, Food, and Resource Economics

Kasara, K. (2007) 'Tax Me If You Can: Ethnic Geography, Democracy and the Taxation of Agriculture in Africa', American Political Science Review 101.1: 159-172

Kaplinsky, R. (2000) ‘Globalization and Un-equalization: What can be Learned from Value Chain Analysis’ Journal of Development Studies 37.2: 117-146

Kaplinsky, R. and Morris, M. (2001) A Handbook for Value Chain Research, Ottawa: International Development Research Centre

Kherallah, M.; Delgado, C.; Gabre-Madhin, E.Z.; Minot, N. and Johnson, M. (2002) Reforming Agricultural Markets in Africa, Baltimore: Johns Hopkins University Press

Kitschelt, H. and Wilkinson, S. (2007) 'Citizen-Politician Linkages: An Introduction', in H. Kitschelt and S. Wilkinson (eds), Patrons, Clients and Policies: Patterns of Democratic Accountability and Political Competition, New York: Cambridge: University Press

Kohansal, M.R. and Mansoori, H. (2009) 'Factors Affecting Loan Repayment Performance of Farmers in KhorasanRazavi Province of Iran', paper presented at the Conference on International Research on Food Security, Natural Resource Management and Rural Development, University of Hamburg, 6-8 October

Kohls, R.L. and Uhl, J.N. (1990) Marketing of Agricultural Products, 6th edition, New York: Macmillan Publishing Company

Ladele, A.A. (2011) 'Approaches to Private Agricultural Extension Service Delivery in Africa: Lessons from Current Development Initiatives in Nigeria', paper presented at the International Conference on Innovation in Extension and Advisory Services, Nairobi, 15-18 November 15-18

Lipton, M. (1977) Why Poor People Stay Poor: A Study of Urban Bias in World Development. London: Temple Smith

Liverpool-Tasie, L.S.O. (2014) 'Fertilizer Subsidies and Private Market Participation: The Case of Kano State, Nigeria', The Journal of the International Association of Agricultural Economists 45.6: 663-678

Liverpool-Tasie, S.L.O.; Auchan, A.A. and Banful, A.B. (2010) An Assessment of Fertilizer Quality Regulation in Nigeria. Nigeria Strategy Support Program (NSSP) Report 09, Washington DC: International Food Policy Research Institute

Liverpool-Tasie, L.S.O. and Takeshima, H. (2013) 'Input Promotion within a Complex Subsector: Fertilizer in Nigeria', The Journal of the International Association of Agricultural Economists 44.6: 581-594

Liverpool-Tasie L.S.O.; Omonona, B.T.; Sanou, A. and Ogunleye, W. (2015) Is Increasing Inorganic Fertilizer Use in Sub-Saharan Africa a Profitable Proposition? Evidence from Nigeria, Policy Research Working Paper 7201, Washington DC: World Bank Group

Liverpool-Tasie, L.S.O. et al. (2017) The Transformation of Value Chains in Africa: Evidence from First Large Survey of Maize Traders in Nigeria, Feed The Future Innovation Lab for Food Security Policy Research Paper 91, Michigan: Michigan State University

Lowitt, K.; Hickey, G.M.; Ganpat, W. and Phillip, L. (2015) 'Linking Communities of Practice with Value Chain Development in Smallholder Farming Systems', World Development, 74: 363-373 
Lyddon, C. (2019) Focus on Nigeria, World Grain, 19 February (accessed 13 April 2021)

Maize Gennovate (2017) Gender and Innovation Processes in Maize-Based Systems, GENOVATE Report to the CGIAR Research Program on Maize, Mexico: International Maize and Wheat Improvement Center (accessed 12 March 2020)

Manyong, V.M. et al. (2003) Agriculture in Nigeria: Identifying Opportunities for Increased Commercialization and Investment, Ibadan: International Institute of Tropical Agriculture

Mason, N.M.; Jayne, T.S. and Van de Walle, N. (2013) 'Fertilizer Subsidies and Voting Behaviour: Political Economy Dimensions of Input Subsidy Programs', paper presented at the Annual Meeting of the Agricultural and Applied Economics Association, Washington DC, 4-6 August

Mather, D. and Jayne, T.S. (2015) 'Fertilizer Subsidies and the Role of Targeting in Crowding Out: An Assessment of Smallholder Fertilizer Demand in Kenya', paper presented at the International Conference of Agricultural Economics, Milan, 9-14 August

Mogues, T.; Kato, E.; Nkonya, E.; Pender, J. and Phillip, D. (2012a) 'Impacts of Community-Driven Development Programmes on Income and Asset Acquisition in Africa: The Case of Nigeria', World Development 40.9: 1824-1838

Mogues T, M.; Morris, L.; Freinkman, A. and Ehui, S. (2012b) 'Agricultural Public Spending in Nigeria', in T. Mogues and S. Benin (eds), Public Expenditures for Agricultural and Rural Development in Africa, London and New York: Routledge, Taylor and Francis Group

Morris, M.; Kelly, V.; Kopicki, R. and Byerlee, D. (2007) Fertilizer Use in African Agriculture: Lessons Learned and Good Practice Guidelines, Washington, DC: World Bank

Mgbenka1, R.N and Mbah, E.N. (2016) 'A Review of Smallholder Farming in Nigeria: Need For Transformation', International Journal of Agricultural Extension and Rural Development Studies 3.2: 43-54

Mpesi, A.M. and Muriaas, R.L. (2012) 'Food Security as a Political Issue: The 2009 Elections in Malawi', Journal of Contemporary African Studies 30.3: 377-383, DOI: 10.1080/02589001.2012.689624

Mutyasira, V. (2019) Value Chain Participants in Smallholder Commercialization in Mvurwi: Emerging Business Relations, APRA blog, 3 September (accessed 8 March 2021)

NAERLS (2017) Nigeria Records Increase in Crops Production Output, Zaria: National Agricultural Extension and Research Liaison Services

Nagy, J.G. and Edun, O. (2002) 'Assessment of Nigerian Government Fertilizer Policy and Suggested Alternative Market-Friendly Policies', paper prepared for the International Fertilizer Development Centre (accessed 22 March 2021)

NASC (2010) A Strategic Plan for the National Agricultural Seeds Council Report, Abuja: SAHEL Consulting

NASC (2015) Annual Report, 2015, Abuja: Federal Ministry of Agriculture and Rural Development

NASC (2017) Annual Report, 2017, Abuja: Federal Ministry of Agriculture and Rural Development

NASC (2019) National Agricultural Seed Council Act (NASC) 2019, Abuja: National Agricultural Seed Council (accessed 17 May 2021)

NBS (2018) Nigerian Gross Domestic Product Report (Q4 \& Full Year 2018), Lagos: National Bureau of Statistics (accessed 17 May 2021) 
Ndaeyo, N.U (2007) 'Assessing the Contributions of Homestead Farming to Food Security in a Developing Economy: A Case Study of Southeastern Nigeria', Journal of Agriculture and Social Sciences 3.1: 11-16

Nelson, G. et al. (2010) Food Security, Farming, and Climate Change to 2050: Scenarios, Results, Policy Options, Washington DC: International Food Policy Research Institute, (accessed 3 March 2020)

NEPAD (2003) Comprehensive Africa Agriculture Development Programme (CAADP), Addis Ababa: African Union (accessed 23 April 2020)

Newsham, A.; Kohnstamm, S.; Naess, L.O. and Atela, J. (2018) Agricultural Commercialization Pathways: Climate Change and Agriculture, APRA Working Paper 9, Brighton: Future Agricultures Consortium (accessed 8 March 2021)

Njiku, J.M.; Kihiyo, V.B.M.; O'ktingati, A. and Place, F. (2006) 'Productivity Differences between Male and Female Managed Farms in the Eastern and Central Highlands of Kenya', paper presented at the International Conference of Agricultural Economists Conference, Gold Coast, 12-18 August

Nkonya, E.; Kato, E.; Johnson, T. and Dayo, P. (2017) End Term Impact of Fadama III Project in Nigeria, Abuja: National Fadama Office

Nkonya, E. et al. (2016) Medium-term Impact Evaluation of Fadama III Project, Washington DC: International Food Policy Research Institute

Nkonya E. et al. (2019) Impact of Fadama III on Food Security and Livelihood Restoration in Northeast Nigeria, Washington D.C: International Food Policy Research Institute

Obi-Egbedi, O. and Bankole, O.A. (2017) 'Determinants of Participation in Fertilizer Subsidy Programme among Rice Farmers in Ogun State, Nigeria', Journal of Development and Agricultural Economics, 9.6: 162-167, DOI: 10.5897/JDAE2017.0818

Obioha, E. (2008) 'Climate Change Population Drift \& Violent Conflict over Land Resources in North-Eastern Nigeria', Journal of Human Ecology 23.4: 311-324

OECD/FAO (2014) OECD-FAO Agricultural Outlook 2014, Paris: OECD Publishing

Odoemenem, I.U. and Obinne, C.P.O. (2010) 'Assessing the Factors Influencing the Utilization of Improved Cereal Crop Production Technologies by Small Scale Farmers in Nigeria', Indian Journal of Science and Technology 3.2: 180-183

Ogundari, K. (2006) 'Determinants of Profit Efficiency among Small Scale Rice Farmers in Nigeria. A Profit Function Approach', Research Journal of Applied Sciences 1.4: 116-122

Ogunniyi, L.T. (2011) 'Determinants of Profit Efficiency Among Small Scale Maize Farmers in Oyo State, Nigeria', ARPN Journal of Agricultural and Biological Sciences 6.1: 11-17

Ogunniyi, L.T. and Omoteso, O.A. (2011) 'Economic Analysis of Swine Production in Nigeria. A Case Study of Ibadan Zone, Oyo State', Journal of Human Ecology 35.2: 137-142

Ogunlela, Y.I. and Mukhtar, A.A. (2009) 'Gender Issues in Agriculture and Rural Development in Nigeria', Humanity and Social Science Journal 4.1: 19-30

Ogunsumi, L.O.; Samuel, O.E. and Adebiyi, G.B.C. (2005) 'Socio-economic Impact Assessment of Maize Production and Technology on Farmers Welfare in Southern Nigeria', Journal of Central European Agriculture 5.1:15-26 
Ojiako, I.A. and Ogbukwa, B.C. (2012) Economic Analysis of Loan Repayment Capacity of Small-holder Cooperative Farmers in Yewa North Local Government Area of Ogun State, Nigeria', African Journal of Agricultural Resources 7.13: 2051-2062

Ojo, S.O. (2000) 'Factors Productivity in Maize Production in Ondo State, Nigeria', Applied Tropical Agriculture 15.1:57-63

Ojo, S.O. and Imoudu, P.B. (2000) 'Efficiency Measurement of Palm Oil Marketing in Ekiti State of Nigeria', African Journal of Business and Economic Research 1.2: 7-12

Olayide, S.O. and Idachaba, F.S. (1987) 'Input and Output Marketing Systems: A Nigerian Case', in J. Mellor, C.L. Delgado and M.J. Blackie (eds), Accelerating Food Production in Sub Saharan Africa, Baltimore: John Hopkins Press

Oladejo, J.A. and Adetunji, M.O. (2012) 'Economic Analysis of Maize (Zea mays) Production in Oyo State of Nigeria. Special Programme for Food Security (SPFS) (2001)', Agricultural Science Research Journals 2.2: 77-83

Olalekan, W. and Bamire, S.A. (2015) 'Determinants of Adoption of Improved Maize Varieties in Osun State, Nigeria', Journal of Agricultural Extension and Rural Development 7.3: 65-72

Olaniyi, L.A. and Adewale, L.A. (2012) 'Information on Maize Production among Rural Youth: A Solution for Sustainable Food Security in Nigeria', Library Philosophy and Practice 4-2012 (accessed 20 March 2021)

Olukosi, J.O.; Isitor, S.U. and Ode, M.O. (2007) Agricultural Marketing and Prices, Principles and Applications, Fourth Edition, Abuja: GU Publishers

Omolola, A.S. (2015) 'The Political Economy of Food Price Policy in Nigeria', in P. Pinstrup-Andersen (ed) Food Price Policy in an Era of Market Instability: A Political Economy Analysis, Oxford: Oxford Scholarship Online

Onyishi, A.O. (2011) 'Governance and Climate Change in Nigeria: A Public Policy Perspective', paper presented at the National Colloquium on Adapting to Climate Change Through Relevant Knowledge, University of Nigeria, Nsukka, 1-3 December

Osundu, C.K.; ljioma, J.C.; Anyiro, C.O. and Obike, K. (2014) 'Economic Analysis of Pig Production in Abia State, Nigeria', International Journal of Applied Research and Technology 3.3: 3-10

Ovwigho, B.O. (2015) 'Role Perception and Performance of Agricultural Extension Agents in Maize Marketing in Delta State, Nigeria', Journal of Biology, Agriculture and Healthcare 5.15: 7-13

Ozor, N., et al. (2010) A Framework for Agriculture Adaptation to Climate Change in Southern Nigeria, a Development Partnerships in Higher Education (DeIPHE) 326 Project Executive Summary supported by DFID and implemented by the British Council, Enugu: African Institute for Applied Economics

Poulton, C. (2014) 'Democratisation and the Political Incentives for Agricultural Policy in Africa', Development Policy Review 32.2: 101-122

Poulton, C. and Chiunsinga, B. (2018) The Political Economy of Agricultural Commercialisation in Africa, APRA Working Paper 16, Brighton: Future Agricultures

Poulton, C. and Kanyinga, K. (2014) 'The Politics of Revitalizing Agriculture in Kenya', Development Policy Review 32.2: $151-172$

Reardon, T.; Mishira, A.; Nuthalapati, C.S.; Bellemare, M.F. and Zilberman, D. (2020) 'Covid-19's Disruption of India's Transformed Food Supply Chains', Economic and Political Weekly Commentary 55.18: 18-22 
Reddy, S.S.; Ram, P.R.; Sastry, T.V.N and Devi, I.B. (2008) Agricultural Economics, Oxford and New Delhi: IBH publishing Co PVT Ltd

Ricker-Gilbert, J.; Jayne, T. and Chirwa, E. (2011) 'Subsidies and Crowding Out: A Double-Hurdle Model of Fertilizer Demand in Malawi', American Journal of Agricultural Economics 93.1: 26-42

Roduner, D. (2004) Report on Value Chains: Analysis of Existing Theories, Methodologies and Discussions of Value Chain Approaches Within the Development Cooperation Sector, paper prepared for the Swiss Agency for Development and Cooperation

Sahel Consulting (2014) The Role of Women in Nigerian Agriculture, Volume 7, Abuja: Sahel Consulting (accessed 22 April 2020)

Sahel Consulting (2017) Maize: Enhancing the Livelihoods of Nigerian Farmers, Volume 14, Abuja: Sahel Consulting (accessed 22 April 2020)

Sahel and West Africa Club/OECD (2006) Joint Mission Report: Food Security and Cross Border Trade in Kano, Katsina, Maradi, France: Secretariat of Sahel and West Africa Club/OECD

Schreinemachers, P.; Wu, M.; Uddin, M.N.; Ahmad, S. and Hanson, P. (2016) 'Farmer Training in Off-season Vegetables: Effects on Income and Pesticide Use in Bangladesh', Food Policy 61: 132-140

Senahoun, J. (2008) Markets, Prices, Food Situation and Prospects for Benin, Niger and Nigeria, based on a CILSS/FAO/FEWSNET/SIMA/WFP Joint Market Assessment Mission to Benin, Niger and Nigeria, Rome: Food and Agriculture Organization of the United Nations

Sennuga, S.S.; Fadiji, T.O. and Thaddeus, H. (2020) 'Factors Influencing Adoption of Improved Agricultural Technologies (IATs) Among Smallholder Farmers in Kaduna State, Nigeria', International Journal of Agricultural Education and Extension 6.2: 382-392

Sheldrick, W.F. and Lingard, J. (2004) 'The Use of Nutrient Audits to Determine Nutrient Balances in Africa', Food Policy 29.2: 61-98

Silong, A. K. F. (2017) 'Credit and the Technical Efficiency of Sheep and Goat Production Among Rural Female Farmers in Nasarawa State, Nigeria', PhD Thesis, University of Reading

Silong A.K.F. (2018) 'The Implications of Gender Power Relations on Small Ruminant Producer Rural Female Farmers in Nasarawa State, Nigeria', The Journal of Development Practice Vol 4, ISSN 2394-0476

Silong, A.K.F. and Gadanakis, Y. (2019) 'Credit Sources, Access, and Factors Influencing Credit Demand Among Rural Livestock Farmers in Nigeria', Agricultural Finance Review 80.1: 68-90

Stein, C. and Barron, J. (2017) Mapping Actors Along Value Chains: Integrating Visual Network Research and Participatory Statistics into Value Chain Analysis, Colombo: International Water Management Institute

Stoorvogel, J.J. and Smaling, E.M. (1990) Assessment of Soil Nutrient Depletion in Sub-Saharan Africa: 19832000, Wageningen: Winand Staring Centre

Takeshima, H. and Nkonya, E. (2014) 'Government Fertilizer Subsidy and Commercial Sector Fertilizer Demand: Evidence from the Federal Market Stabilization Program (FMSP) in Nigeria', Food Policy 47:1-12

Thomas, J. and Grindle, M. (1990) 'After the Decision: Implementing Policy Reforms in Developing Countries', World Development 18.8: 1163-81 
Tolentino, P.E. (2010) 'Home Country Macroeconomic Factors and Outward FDI of China and India', Journal of International Management 16.2: 102-120

Ugwumba, C.O.A (2009) 'Analysis of Maize Marketing in Anambra State, Nigeria', Journal of Research in National Development 7.2

United Nations (2002) 'Monterrey Consensus on Financing for Development', the final agreements and commitments that were adopted at the International Conference on Finance for Development, Monterrey, Mexico, 18-22 March

USAID (2010) Packages of Practices for Maize Production, Washington DC: United States Agency for International Development's Maximizing Agricultural Revenues and Key Enterprises in Targeted Sites (MARKETS)

USAID (2018) Maximizing Agricultural Revenue and Key Enterprises in Targeted Sites in Nigeria. Final Performance Evaluation Report, Washington DC: United States Agency for International Development

USDA (2012) Assessment of Commodity and Trade Issues: Nigeria Grain and Feed Annual Report, GRAIN Report Number: NG-19002, Washington DC: United States Department of Agriculture

USDA (2020) Foreign Agricultural Service Grain: World Markets and Trade, Washington DC: United States Department of Agriculture

Vermeulen, S.; Woodhill, J.; Proctor, F.J. and Delnoye, R. (2008) Chain-Wide Learning for Inclusive Agrifood Market Development: A Guide to Multi-Stakeholder Processes for Linking Small-Scale Producers with Modern Markets', Wageningen: Wageningen University and Research Centre

Walton, J.K. and Seddon, D. (2008) Free Markets and Food Riots: The Politics of Global Adjustment, California: John Wiley and Sons

Woodhill, J. and Van Vugt, S. (2008) Facilitating Multi-stakeholder and Institutional Change Process: A Societal Learning Process, Wageningen: Wageningen University and Research Centre

World Bank (2014) Agribusiness Indicators for Nigeria, Washington DC: World Bank

World Bank (2008) World Development Report 2008: Agriculture for Development, Washington DC: World Bank

Wrong, M. (2009) It's Our Turn to Eat: The Story of a Kenyan Whistle-blower, London: Fourth Estate

Xu, Z.; Guan, Z.; Jayne, T.S. and Black, R. (2009a) 'Profitability of Applying Fertilizer on Maize for Smallholder Farmers in Zambia', Agricultural Economics Journal 40.4: 437-446

Xu, Z.; Burke, W.; William, J.; Jayne, T.; and Govereh, J. (2009) 'Commercial Market Development? Modelling Fertilizer Use Decisions in a Two-Channel Marketing System', Agricultural Economics Journal 40.1:79-94

Yesuf, M.; Difalce, S.; Riungler, C. and Kollam, G. (2008) The Impact of Climate Change and Adaptation on Food Production in Low-income Countries: Evidence from the Nile Basin, Ethiopia, Washington DC: International and Production Technology Division, International Food Policy Research Institute

Zoellick, R.B. (2009) 'A Climate Smart Future', Stabroek News, 19 September (accessed 17 May 2021) 


\section{Annex A: Study questions}

The study focused on four topic areas: (1) an overview of the MVC; (2) mapping the value chain; (3) policy making concerning the value chain, and (4) social differences within the chain. The research questions are as follows:

\section{An overview of the MVC:}

- Are there any changing patterns in the political importance of the MVC?

- What have been the key drivers of the performance of the MVC?

- What is the current performance of the MVC, with high-level reasons for why it is performing as it is?

\section{Mapping the MVC}

- What is the final market(s) for maize?

- What are the major market requirements?

- What are the different stages and processes along the MVC?

- What are the main technical challenges that value chain actors must overcome to ensure competitiveness?

- How many players are involved at each stage of the MVC? Who are they?

III. Policy making concerning the MVC

- What are the major changes in policies along the MVC?

- What are the major current policies and regulations that govern participation in the MVC?

- Which of these policies are most contested, by whom and why?

- Who sets these policies and regulations?

- Who seeks to influence policy within the MVC, and how?

- Are there new considerations with relevance to emerging policy agendas and funding on climateresilient or climate-smart agriculture?

\section{Social difference within the MVC:}

- Which relevant social groups can be identified in the narrative of commercialisation of the MVC? What are their interconnections across scales and farm sizes?

- How is labour organised in the MVC, what are the implications of this for different groups, and how does this interact with other labour requirements, including unpaid care?

- Has commercialisation had different outcomes and impacts for different groups?

\section{Annex B: A list of MVC actors that participated in the KIIs}

\section{Primary maize producers (farmers):}

1. Nuhu Aminu, Chairman, Maize Farmers Association, Zaria, Kaduna State

2. Saleh Saidu, Chairman, Fadama Farmers Association, Zaria, Kaduna State

3. Elijah Ishaku, Head of Operations, Babban Gona Farmers' Services Limited, Ikara, Kaduna State

\section{Fertiliser input suppliers:}

4. Aliyu Ahmed Bakure, Zaria, Kaduna State

\section{Seed producers and suppliers}

5. Prof. A. O Ogungbile, Premier Seeds Limited, Zaria, Kaduna State

6. Stephen Atar, Managing Director/CEO, Da All-Green Seeds Limited, Kaduna State, Kaduna State 
Wholesale maize marketers:

7. Salisu A. Nuhu, Managing Director/CEO, Salisu A. Nuhu and Sons Limited, Zaria, Kaduna State

8. Zubairu Fatika, Zaria, Kaduna State

9. Daguda Tahiru, Giwa Market, Kaduna State

10. Hamisu Yahaya, Chairman, Giwa Grains Marketers, Giwa, Kaduna State

\section{Processing industries:}

11. Alao Rotimi, Head of Supply Chain, Hybrid Feeds Limited, Kaduna State

\section{Research institutes:}

12. Prof. D. A. Abba, Researcher, Institute of Agricultural Research, ABU, Zaria, Kaduna State

\section{Credit institution:}

13. Felix Ehindero, Branch Manager, Bank of Agriculture, Zaria, Kaduna State

\section{Policy:}

14. Lucas Garba, Director, Extension, Kaduna State ADP

15. Danjuma Tyuka, Director, Monitoring and Evaluation, Kaduna State ADP

16. Programme Manager, Plateau State ADP

17. David Darina, Director, Finance and Administration, Plateau State, ADP

18. Sati Dagal, Chief Research Officer, Plateau State ADP

\section{Annex C: KII guide}

\section{Introduction}

The KII is being carried out to determine the roles of different actors along the MVC, vis à vis the interplay of state policies in the commercialisation of maize. The lead questions here are not cast on stone. It is just a guide, which can be used flexibly to gather more information on the MVC.

The Major actors identified in the MVC are itemised below:

9. Maize farmers' Associations

10. Fadama maize farmers (Kaduna, Kano)

11. Commercial maize farmers (Babban Gona, Kaduna, Mangu, Saminaka)

12. Fertilizer input suppliers

13. Seed companies (Da All Green - Kaduna, Premier Seeds)

14. Marketers (wholesalers and warehousing)

15. Value addition/processors (Grand Cereals and NASCO)

16. Research institutes (IITA, Kano, the Institute for Agricultural Research)

17. Credit Institutions (NIRSAL, Bank of Agriculture, commercial banks)

18. Policy makers (FMARD/ADP)

\section{Maize farmers' associations/Fadama maize farmers (Kaduna, Kano)}

1. How long have you been farming maize?

2. Do you consider maize production profitable?

3. Where do you source your production inputs? (foreign or local markets)

4. Where do you sell your maize grain? (foreign or local markets)

5. Is the Fadama group registered? (If yes, provide name)

6. Are there institutional rules/policies guiding your operations?

7. Who made the rules?

8. Do you have operational guidelines guiding your operations?

9. Does change in regime/government affect your activities and operations? (If yes, what is the nature of the effect, when did it specifically happen?)

10. What are the challenges hinderingyour expansion? (Identify the major challenges to commercialisation and their promoters)

11. What should be the possible solutions? 


\section{Commercial maize farmers}

1. How long have you been farming maize?

2. What is the name of your farm?

3. Is it formally registered?

4. How many people do you employ?

5. Where do you source your production inputs? (foreign or local markets)

6. Where do you sell your maize grains? (foreign or local markets)

7. Are there institutional rules/policies guiding your operations?

8. Who made the rules?

9. Do you have operational guidelines guiding your operations?

10. Does change in regime/government affect your activities and operations? (If yes, what was the nature of the effect, when did it specifically happen?).

11. What are the challenges hindering your expansion? (Quality of maize, climate change, access to inputs, state and non-state actors that serve as impediments)

12. What do you think should be the solutions?

\section{Fertiliser input suppliers/seed companies}

1. From where do you source your goods/supplies? (foreign or local markets)

2. Do you pay taxes/levies?

3. How much do you pay per consignment?

4. Do you consider the taxes/levies exorbitant?

5. Who are your major buyers?

6. Does change in regime/government affect your activities and operations? (If yes, what was the nature of the effect, when did it specifically happen?)

7. What challenges are hindering your business?

8. What do you think should be the solutions?

\section{Marketers}

1. Where do you source your supplies?

2. What time of the year do you make your purchases?

3. Where do you sell your maize? (foreign or local markets)

4. Who are your major buyers?

5. Are there barriers to entering the markets? (If yes, identify the barriers and their promoters. Also identify their gains)

6. What challenges do you face in selling your maize?

7. What should be the solutions?

\section{Value addition/processors}

1. What products do you make from maize?

2. Where do you sell your products?

3. Is your firm formally registered?

4. Are there barriers to being a processor? (If yes, identify the barriers and their promoters. Also identify their gains)

5. From where do you source your maize grain? (foreign or local markets)

6. What challenges do you have in purchasing your raw materials (maize grain)?

7. Do you have enough storage facilities for your raw materials (maize grain)?

8. From where do you source your machineries? (foreign or local markets)

9. What challenges do you face in sourcing your machineries?

10. What type of power drives the machineries in your firm? (Provide number of hours if national grid is used and number of hours if diesel is used).

11. Do you enjoy any incentives from the government?

12. How many people are in your employment?

13. Has the patronage for your products increased or declined in relation to the income status of Nigerians?

14. Does change in regime/government affect your activities and operations (If yes, what was the nature of the effect, when did it specifically happen?) 
15. What challenges do you have in selling your products?

16. What should be the solutions to the challenges?

\section{Federal Ministry of Agriculture (FMARD)/State ADPs}

1. Is maize among the targeted crops in the State?

2. What specific policies/incentives are put in place to promote its production across the value chain? (Tax relief, any form of moratorium etc.)

3. Who benefits from the policies? (Maize farmers, processors or are they hijacked by State actors)

4. When did the policy/incentive become operational in the State?

5. What challenges are hindering maize production and development of the value chain in the State?

6. What should be the solutions to the challenges?

\section{Research institutes}

1. How long have you been involved in maize research?

2. What advances did you make from the research?

3. Is the result of the research accepted and used by farmers?

4. What do you think are the hindrances to the commercialisation of maize in the country?

5. What do you think are the major challenges to self-sufficiency in maize production in the country?

6. Does change in regime/government affect your activities and operations (If yes, what was the nature of the effect, when did it specifically happen?)

7. What general challenges do you face that hinder MVC development?

8. What should be the solutions?

\section{Credit institutions}

1. Do you have schemes targeted at developing maize and the MVC? (If yes, what are they?)

2. Do the policies target small or commercial farmers? Are they gender sensitive?

3. What is the extent of patronage of maize famers and value chain actors to boost their operations?

4. Is maize production on the increase or on the decrease?

5. Who patronises you most? (Farmers, politicians etc.)

6. Has maize price affected your patronage over the years?

7. How do you rate your contribution to maize: production, marketing, and processing?

8. What challenges do you face in boosting the MVC?

9. What should be the solutions?

\section{Policy makers}

1. Are there policies governing maize and its value chain operations? (If yes, what are they?)

2. Are the policies targeted at small scale or commercial farmers?

3. Who initiated the policies? (Federal government, State governments, NGOs, farmer groups etc.)

4. When was the policy formulated and implemented?

5. Do you consider the policy to be effective? (If yes, mention specific achievements)

6. How can you rate the impact of the policies on the MVC?

7. Does the policy come with any incentives in support of the MVC? (Do the MVC actors take advantage of the incentives or is it being hijacked by non-actors?)

8. What are the challenges to the implementation of the policies?

9. What are the challenges to the commercialisation of maize and its value chain in the country?

10. What should be the solutions to the challenges? 
Amaza, P.; Mailumo, S. and Silong, A. (2021) The Political Economy of the Maize Value Chain in Nigeria, APRA Working Paper 60, Brighton: Future Agricultures Consortium

(c) APRA 2021

ISBN: 978-1-78118-820-0

DOI: 10.19088/APRA.2021.015

\section{(c) BY-NC-ND}

This is an Open Access report distributed under the terms of the Attribution-Non Commercial-No Derivs 4.0 Unported (CC BY-NC-ND 4.0) Attribution - You must give appropriate credit, provide a link to the license, and indicate if changes were made. You may do so in any reasonable manner, but not in any way that suggests the licensor endorses you or your use. NonCommercial — You may not use the material for commercial purposes. NoDerivatives - If you remix, transform, or build upon the material, you may not distribute the modified material. You are free to: Share - copy and redistribute the material in any medium or format.

https://creativecommons.org/licenses/by-nc-nd/4.0/legalcode

If you use the work, we ask that you reference the APRA website (www.future-agricultures.org/apra/) and send a copy of the work or a link to its use online to the following address for our archive: APRA, Future Agricultures Consortium, University of Sussex, Brighton BN1 9RE, UK (apra@ids.ac.uk)

All APRA Working Papers go through a review process before publication.

\section{Ccreative}

DO YOU HAVE COMMENTS ON THIS PAPER?

We would welcome your feedback on this working paper!

To provide brief comments, please follow this link to our short APRA Working Paper Feedback form: https://goo.gl/forms/1iVnXhhrlGesfR9

Agricultural Policy Research in Africa (APRA) is a programme of the Future Agricultures Consortium (FAC) which is

generating new evidence and policy-relevant insights on more inclusive pathways to agricultural commercialisation in sub-Saharan Africa. APRA is funded with UK aid from the UK Foreign, Commonwealth \&

Development Office (FCDO) and will run from 2016-2022.

The APRA Directorate is based at the Institute of Development Studies (IDS), UK (www.ids.ac.uk), with regional hubs at the Centre for African Bio-Entrepreneurship (CABE), Kenya, the Institute for Poverty, Land and Agrarian Studies (PLAAS), South Africa, and the University of Ghana, Legon. It builds on more than a decade of research and policy engagement work by the Future Agricultures Consortium (www.future-agricultures.org) and involves more than 100 researchers and communications professionals in Africa, UK, Sweden and USA. 